University of Wollongong

Research Online

Faculty of Business - Papers (Archive)

Faculty of Business and Law

$1-1-2013$

The impact of China's new labour contract law on socioeconomic outcomes for migrant and urban workers

Zhiming Cheng

University of Wollongong, zhiming@uow.edu.au

Russell Smyth

Monash University

Fei Guo

Macquarie University

Follow this and additional works at: https://ro.uow.edu.au/buspapers

Part of the Business Commons

Research Online is the open access institutional repository for the University of Wollongong. For further information contact the UOW Library: research-pubs@uow.edu.au 


\title{
The impact of China's new labour contract law on socioeconomic outcomes for migrant and urban workers
}

\author{
Abstract \\ This paper examines the effect of having a labour contract on a range of employee outcomes (hours \\ worked, social insurance coverage, subjective wellbeing and wages) for a sample of urban and migrant \\ workers in China. A methodological contribution is that we use propensity score matching, which allows \\ us to draw causal inferences about the relationship between having a labour contract and each of these \\ variables. We find that the effect of having a labour contract on employee outcomes is generally large and \\ larger than the findings in other studies suggest. As such, our results suggest that China's Labour \\ Contract Law, which has made signing labour contracts mandatory, has been effective in improving the \\ outcomes for Chinese workers.

\section{Keywords} \\ urban, migrant, outcomes, socioeconomic, law, contract, labour, workers, china, impact \\ Disciplines \\ Business

\section{Publication Details} \\ Cheng, Z., Smyth, R. \& Guo, F. (2013). The impact of China's new labour contract law on socioeconomic \\ outcomes for migrant and urban workers. Monash University. Department of Economics. Discussion \\ Papers, 51/13 1-31.
}




\title{
DEPARTMENT OF ECONOMICS
}

ISSN 1441-5429

DISCUSSION PAPER 51/13

\section{The Impact of China's New Labour Contract Law On Socioeconomic Outcomes for Migrant and Urban Workers}

\author{
Zhiming Cheng," Russell Smyth` and Fei Guo`
}

\begin{abstract}
This paper examines the effect of having a labour contract on a range of employee outcomes (hours worked, social insurance coverage, subjective wellbeing and wages) for a sample of urban and migrant workers in China. A methodological contribution is that we use propensity score matching, which allows us to draw causal inferences about the relationship between having a labour contract and each of these variables. We find that the effect of having a labour contract on employee outcomes is generally large and larger than the findings in other studies suggest. As such, our results suggest that China's Labour Contract Law, which has made signing labour contracts mandatory, has been effective in improving the outcomes for Chinese workers.
\end{abstract}

\footnotetext{
* School of Economics, University of Wollongong

- Department of Economics and Centre of Development Economics, Monash University

^ Department of Marketing and Management, Macquarie University
} 


\section{Introduction}

There is a lot of interest in the effect of employment protection legislation (EPL) on labour market outcomes around the globe. To this point, the evidence on the effectiveness of EPL has been mixed. Some studies have found that EPL is effective in generating positive labour market outcomes for workers (Alvarez \& Veracierto, 1998; Bentolila \& Bertola, 1990). However, other studies have found that EPL has no effect on outcomes for workers (Ahsan \& Pages, 2009; Paes de Barros \& Corseuil, 2004) or that the outcomes can be negative (Besley \& Burgess, 2004; Lin, 2013).

China's new Labour Contract Law, which came into effect in 2008, represents a significant piece of EPL in the world's largest transition economy. The Labour Contract Law has been described as "the most significant reform to the law of employment relations [in China] in more than a decade" (Cooney, Biddulph, Li \& Zhu, 2007, p. 786). It has been suggested that the "new law [has] aroused more public debate than perhaps any piece of legislation in the history of China" (Friedman \& Lee, 2010, p. 525). The Labour Contract Law requires all workers to have a written contract and states that any employer with an employee without a written labour contract is required to double his or her wages for each month worked without a contract, beginning with the second month. The Labour Contract Law also specifies that any employee who has worked for more than a decade with an employer and signed two successive fixed term contracts, must be given a open-ended contract. Finally, the Labour Contract Law reaffirms pre-existing social insurance, wage and maximum working hour obligations on employers (Cooney et al., 2007; Li, 2008). While concern was expressed, at least initially, about the extent to which it would be enforced (see eg. Zheng, 2009) a feature of China's Labour Contract Law is that the regulations are strict, relative to other countries. Based on the measure of EPL strictness applied to OECD countries (OECD, 2004), China would rank third in terms of EPL strictness among OECD countries (Gallagher, Giles, Park \& Wang 2013).

China's Labour Contract Law represents a good opportunity to study the effectiveness of EPL in an economy with a fast evolving labour market. Some recent studies have taken the opportunity to examine the effect of China's new Contract Law on a range of worker benefits (see eg. Cheng, Nielsen \& Smyth 2014; Cui, Ge \& Jing, 2013; Freeman \& Li, 2013; Gallagher et al. 2013; Gao, Yang \& Li, 2012; Wang, Guo \& Cheng 2013). The results from these studies suggest that the Contract Law has improved employee benefits, particularly for migrant workers. However, despite the large potential impact of the new law on China's urban workforce, there is still a dearth of empirical evidence on the effectiveness of the legislation.

In this paper we use propensity score matching to evaluate the effect of the Contract Law on a number of outcomes for migrant and urban workers, in which having a labour contract is considered as a treatment. Using this approach, we examine the labour market outcome of a given employee who is treated (ie. has a labour contract) with the hypothetical labour market outcome that would have prevailed if the same worker had not been treated (ie. did not receive a labour contract).

We make the following contributions to the existing literature. First, we add to the paucity of existing empirical evidence on the effectiveness of the Chinese Contract Law in improving the wellbeing of migrant and urban employees. Second, we 
consider a range of labour market and socioeconomic outcomes (hours worked, social insurance coverage, subjective wellbeing and wages). This is a much broader range of outcomes than previous studies, which have tended to focus on specific labour market outcomes such as access to social insurance (Freeman \& Li, 2013; Wang et al., 2013; Cheng et al., 2014; Gao et al 2012), wage and non wage benefits (Cui et al 2013) or the incidence of wage arrears (Freeman \& Li, 2013).

A third contribution is that, in contrast to previous studies, which have used firm level data to analyse the effect of labour contracts on wages, we use individual-level data. A limitation of using firm level data is that it is not possible to account for individual heterogeneities. For example, employing firm level data, Cui et al (2013) construct a variable for the firm level wage by dividing total wage expenditure by the number of employees in the firm, thus obfuscating important microeconomic effects.

A fourth contribution is that we include a full set of controls in all regressions. Specifically, in the wages regression we control for experience and years of schooling and in the hours worked regression we control for wages, consistent with theoretical considerations and broader literature on the determinants of labour supply and wages. Previous studies only include a limited number of controls, which potentially biases the estimates. For example, in examining the effect of labour contracts on wages Cui et al (2013) do not control for years of schooling or experience.

Finally, a major problem with the extant literature is that it fails to address the fact that whether an employee has a labour contract is endogenous (ie. employees who have more ability, or are better credentialed, are more likely to have labour contracts). We make a methodological contribution to the literature in that we use a novel method (propensity score matching) to address the endogeneity problem that has plagued previous studies examining China's Labour Contract Law. Propensity score matching reduces potential endogeneity and allows us to draw causal inferences about the effect of labour contracts on employee outcomes with non-experimental data.

\section{China's Labour Contract Law}

China's Labour Contract Law was passed by the Standing Committee of the National People's Congress on June 29, 2007 and started to take effect on January 1, 2008. The law is intended to specify the rights and obligations of parties to labour contracts and to give employees more legal rights to protect job security. While the law was welcomed by non-government organisations (NGOs) and worker rights' advocates, it was criticized by employer groups who predicted that it would have a negative effect on the competitiveness of business in China (Becker \& Elfstrom, 2010). In initial modelling of the impact of the law, Chen and Funke (2009) concluded that the Labour Contract Law would have only a small effect upon employment and possibly that induced labour costs might adversely effect employment. In the lead-up to the legislation coming into force, employers used a range of methods to avoid their impending legal obligations, such as firing and then rehiring the same workers to get around the provisions granting ten-year employees transfer to non-fixed-term contracts. Well-publicised instances of this occurred when Huawei and LG China laid-off workers, only to immediately rehire them, to avoid signing open-ended contracts. NGOs and the unions responded by mounting mass "legal publicity" ( $p u f a$ ) events to increase worker awareness of the legislation (Becker \& Elfstrom, 2010). 
In the aftermath of the legislation coming into operation, much concern was expressed about whether it would be enforced (Zheng, 2009). A prevailing view was that the only firms that would comply with the law would be multinational enterprises and state-owned enterprises (SOEs) and that it would have little effect on worker wellbeing (Freeman \& Li, 2013). An often-made argument was that the workers would be unable to enforce their rights. It is well known that in China that the All China Federation of Trade Unions - the only official trade union - is more aligned with the government and firms than with workers (Zheng, 2009). While the coverage of the law is intended to be national, in practice it is left to sub-provincial level officials to implement the law. It might not be in the best interests of local officials to enforce the law if it has an adverse effect on investment in the local region (Cui et al., 2013). Even if the sub-provincial officials were minded to enforce the law, most faced severe resource constraints. For example, one survey found that there were just 137 labour inspectors supervising 500,000 enterprises in Guangzhou (Cui et al., 2013).

Nevertheless, despite the initial scepticism that the Labour Contract Law would have any difference, there is evidence that the proportion of employees signing contracts has increased. Based on a survey of almost 600 human resources managers, Cheng and Yang (2010) found that the Labour Contract Law has increased the likelihood of signing contracts, increased the number of open-ended contracts and resulted in more careful recruitment, and dismissal, decisions. According to official statistics, in 2010, 97 per cent of employees had signed contracts. In addition, according to the official statistics, in 2010 there were about 9.2 million collective contracts, covering about 114 million employees, which was 76.5 per cent higher than in 2007 (Cui et al., 2013). Cheng, Wang and Chen (2014) and Gallagher et al. (2013) provide statistics on the prevalence of labour contracts, based on the 2009 Migrant Workers Survey in the Pearl River Delta of Guangdong Province (MWS-PRD) and the 2010 China Urban Labour Survey (CULS) respectively. ${ }^{1}$ The numbers are not as impressive as the official statistics. Based on the 2009 MWS-PRD, 62 per cent of migrant workers signed labour contracts, among which the majority (78 per cent) were short (less than 1 year) and medium terms (1-3 years). Based on the 2010 CULS, 71 per cent of urban locals and 34 per cent of migrants had signed labour contracts. This, however, still represented a significant improvement over coverage in the 2001 and 2005 CULS. $^{2}$ The 2010 CULS also asked respondents about awareness of the Labour Contract Law. Almost all workers (95 per cent of urban locals and 89 per cent of migrants) knew they had a right to sign a labour contract. Most knew that they were entitled to be paid double wages for each month worked beyond the period in which the labour contract should have been signed ( 81 per cent of urban locals and 77 per cent of migrants).

\footnotetext{
1 The 2009 MWS-PRD covered nine cities in the Pearl River Delta in Guangdong province which is the largest destination for migrant workers, and the 2010 CULS covered five cities (Shanghai, Shenyang, Wuhan, Xian and Fuzhou).

2 Based on the data employed in the present study, 90.5 per cent of urban workers, and 65.8 per cent of migrant workers, had signed labour contracts in 2008 - see Table 1 below.
} 


\section{Existing Literature}

As noted in the introduction, the literature on the effectiveness of the Labour Contract Law on worker wellbeing is relatively scant. There are few studies that examine the effect of having a labour contract on the probability that migrants and/or urban locals will receive social insurance, controlling for the demographic and human capital characteristics of the individual (Cheng et al., 2014; Freeman \& Li, 2013; Gao et al., 2012; Gallagher et al., 2013; Wang et al., 2013). Each of these studies finds that signing a labour contract increases the likelihood of receiving social insurance. Some of these studies suggest that for migrant workers, signing a labour contract is becoming more important than household registration (hukou) status in determining access to social insurance schemes (Cheng et al., 2014; Gao et al., 2012).

In addition to examining the effect of migrants signing a labour contract on social insurance coverage, Freeman and Li (2013) examined the effect of migrants signing a contract on the likelihood of wage arrears and the likelihood of a union presence in the workplace. They found that if a migrant worker signed a labour contract this reduced the likelihood of experiencing wage arrears and increased the likelihood of having a union presence in their workplace. Similarly, as well as considering the effect of urban workers' signing a labour contract on social insurance coverage, Wang et al. (2013) examined the effect of signing a labour contract on other employee benefits, such as being granted leave on public holidays and weekends, and find that urban workers who signed contracts are more likely to receive these benefits. Finally, using panel data collected from manufacturing enterprises from 1998 to 2008, Cui et al. (2008) found that the Labour Contract Law improved average wage and average non-wage compensation and reduced the wage elasticity of labour demand.

To summarize, there are few studies that have examined the effect of the Labour Contract Law on employee outcomes for migrants and/or urban locals, despite considerable speculation about the efficacy of the legislation in addressing its stated purpose. Of those studies that do exist, most focus on one or two specific benefits, rather than considering a more comprehensive range of outcomes. In addition, the existing literature does not specifically address the fact that signing a labour contract is endogenous. These are limitations we seek to address in the current study.

\section{Data}

The data used in this study was collected in 2008 by the Rural-Urban Migration in China (RUMiC) project at the Australian National University. The sample size is 18,000 households (5,000 rural-urban migrant, 5,000 urban and 8,000 rural households) in 15 cities of the nine largest municipalities/provinces in terms of sending and receiving migrants. These municipalities/provinces are: Shanghai, Jiangsu, Zhejiang, Hubei, Henan, Anhui, Chongqing, Sichuan and Guangdong. ${ }^{3}$ The analysis in the present study is restricted to migrant and urban households. The sample is further limited to individuals, aged 16-64, who work in a paid job. Thus, the final sample consisted of 4756 migrant workers and 6239 urban workers.

\footnotetext{
${ }^{3}$ See http://rse.anu.edu.au/rumici/ for more information about the project including a map of survey regions.
} 
The sample size across the cities was distributed according to the overall population size of the city. For urban households, the sampling design was based on that of the official annual urban household survey, which is administered by the National Bureau of Statistics of China. For rural-urban migrant households, the RUMiC project team conducted a census of all work places in each of the 15 target cities and then used the total number of workers, and the total number of migrant workers, in these workplaces to estimate the size of the migrant worker population in each of the cities. The census information provided a sampling framework for subsequent random sampling within each selected workplace. Interviewers selected the final sample of migrant workers based on randomly selected birth month and then made an appointment with them to interview the individuals and their families. ${ }^{4}$

Table 1 presents descriptive statistics for migrant and urban workers. Without controlling for other variables, migrant workers and urban workers with a labour contract have higher hourly and monthly wages, less monthly working hours, higher subjective wellbeing indicators and higher incidence of access to employee benefits (ie. industrial injury and unemployment insurance, housing provident fund and superannuation). ${ }^{5}$ The differences are more significant among urban workers than migrant workers, except for monthly working hours and subjective wellbeing.

[Table 1 here]

\section{Methodology}

\section{Treatment effect of labour contract in regression modelling}

We first examine the probability of signing a labour contract (Equation 1) and then the relationship between signing a labour contract and employee outcomes (wages, hours worked, subjective wellbeing and access to employee benefits) (Equation 2):

$$
\text { Contract }_{i}=\lambda+\mu \cdot X_{i}+v_{i}
$$

$Y_{i}=\alpha+\beta \cdot$ Contract $_{i}+\gamma \cdot X_{i}+\varepsilon_{i}, \varepsilon_{i}=\delta_{i}+\theta_{i}$

Here Contract $_{i}$ denotes whether the $i$ th worker has a labour contract (set equal to 1 if the worker has a labour contract; otherwise zero) at the time of survey; $Y$ is the employee outcome; $X$ is a vector of control variables and $v$ or $\varepsilon$ is an error term containing the effects of unobserved variables $(\delta)$ and the non-linear effect of observed variables $(\theta)$. A logit model is used to estimate Equation 1. To estimate Equation 2, ordinary least squares (OLS) regression is used when $Y$ denotes wages, hours worked or subjective wellbeing, while a logit model is used when $Y$ denotes

\footnotetext{
${ }^{4}$ Within each city the sampling frame for migrants is defined on the basis of workplaces rather than residence. This is mainly because a sizable proportion of migrant workers in China live in workplace dormitories, construction sites and other workplaces. Thus, the residential based sampling would be biased due to the omission of this group of migrants - see Kong (2010) for more details.

${ }^{5}$ In this study subjective wellbeing is evaluated using the General Health Questionnaire-12 (GHQ-12), which is designed to assess psychological wellbeing. GHQ, as a measure of subjective wellbeing, has been widely employed in the economics and psychology literature (see eg. Clark \& Oswald, 1994, 2002). Following the study by Akay, Giulietti, Robalino and Zimmermann (2013), we add the scores of the 12 standard questions, which contain responses with scores from 0 to 3 (from worst to best), to obtain an overall index of subjective wellbeing, which ranges from 0 to 36. For a previous study using the GHQ-12 from the RUMiC, see Friedman (2013).
} 
participation in social insurance or other employee benefits (set equal to 1 if the individual participates in the specific scheme; otherwise zero). ${ }^{6}$

In Equation 2, if there are no unobservable heterogeneous factors that affect the probability of signing a labour contract and the outcome variable, the coefficient $\beta$ identifies the average effect of signing a labour contract on the employee outcome. However, it is unlikely that controlling for even a rich set of variables will completely eliminate the selection bias contained in almost any non-experimental data.

Conceptually, it is difficult to draw conclusions about a causal effect running from signing a labour contract to employee outcomes because of potential endogeneity. The results may be biased because the residual (depicted by $\delta$ in Equation 2) may contain factors related to having a labour contract, which are not captured by observed variables, such as education, gender, and age. In the context of this study, workers with more ability may be more likely to be offered labour contracts by employers. In other words, one's labour contract status may not be exogenously determined solely by the legal requirements of the Labour Contract Law, but, at least in part, may depend on one's ability and other unobserved credentials, as evaluated by one's employer. Those workers with more ability would earn higher-than-average wages in the labour market, irrespective of whether they have a labour contract.

\section{Treatment effect of labour contract in propensity score matching}

In order to draw causal inferences about the effect of signing a labour contract on employee outcomes, we employ a matching estimator, using propensity score matching. This entails asking the question: What is the outcome (in terms of wages, hours worked, access to employee benefits and subjective wellbeing) for worker $i$ who is treated (here, signed a contract), relative to the hypothetical outcome that would have prevailed if the same worker had not been treated (signed a contract)?

The treatment effect approach can reduce potential endogeneity, alleviate bias due to systematic difference and allow one to draw casual inference in non-experimental labour studies (Dehejia, 2005; Dehejia \& Wahba, 2002). In contrast to using OLS, the propensity score matching approach does not necessarily need to assume a linear relationship when conditional independence is assumed. This implies that treatment effect results are unbiased compared to OLS results. Moreover, even if there exists unobserved variables, the treatment effect approach can assign different weights to individual samples, depending on their probability of having a labour contract based on observed variables. The weights can reasonably reflect unobserved variables.

In the case of a binary treatment, the treatment indicator is the treatment variable (set equal to 1 if worker has a labour contract; otherwise zero). The potential outcomes are then defined as $Y_{i}\left(D_{i}\right)$ for each worker $i$, where $i=1, \ldots, N$ and $N$ denotes the population. The average treatment effect (ATE) for worker $i$ (ie. a randomly selected worker from the population) can be written as:

\footnotetext{
${ }^{6}$ When the labour market outcome is wage, Equation 2 is an extended form of the Mincer wage equation. When the labour market outcome is hours worked, we include wage rate per hour on the right hand side. For subjective wellbeing, using OLS entails treating subjective wellbeing as cardinal as opposed to ordinal, which would entail employing an ordered logit model. Estimates of the determinants of subjective wellbeing have been found to be not sensitive to treating subjective wellbeing as ordinal or cardinal (see Ferrer-i-Carbonell and Frijters, 2004 or Knight, Song \& Gunatilaka 2009 for an application with Chinese data).
} 
where $E(\cdot)$ denotes the mathematical expectation operation, ie. the population average of a random variable; $D_{i}$ is the treatment variable (takes the value 1 if the $i$ th worker has a labour contract, zero otherwise); $Y_{i}(1)$ is the employee outcome variable in the treatment state and $Y_{i}(0)$ is the employee outcome variable in the non-treatment state. However, the treated workers cannot be observed in the non-treatment state. In other words, only one of the potential outcomes is observed for each worker $i$. Therefore, it is necessary to construct the unobserved, or counterfactual, outcome.

The counterfactual mean for those being treated $[E(Y(0) \mid D=1)]$ is unobservable. Therefore, one has to choose a proper substitute for it in order to estimate the average treatment effect. If a treatment is randomized, under certain assumptions it is sufficient to compare the average outcome of the treated group $[E(Y(1) \mid D=1)]$ and untreated (control) group $[E(Y(0) \mid D=0)]$. The difference in these two average outcomes is regarded as the average treatment effect on the treated (ATT):

$A T T=E[Y(1) \mid D=1]-E[Y(0) \mid D=0]$

In a randomised experiment, the average outcome of the untreated group (those who have not signed a labour contract) is a consistent estimate of the counterfactual $[E(Y(0) \mid D=0)]$ for the treated group (those who have signed a labour contract) if there is no randomization and substitution biases (Heckman \& Smith, 1995):

$E[Y(0) \mid D=1]-E[Y(0) \mid D=0]$

However, having a labour contract is not a randomised experiment in observational data, such as that contained in RUMiC. The objective of the propensity score matching approach is to make the average outcome of the untreated group $[E(Y(0) \mid D=0)]$ as similar as possible to that of the counterfactual $[E(Y(0) \mid D=1)]$. In order to identity a casual treatment effect, similar to other studies applying propensity score matching to observational data, we invoke the conditional independence assumption. ${ }^{7}$ In this study, conditional on workers' characteristics, the potential outcome in the untreated state is independent of the treatment status:

$E(Y(0) \mid D=1, P(X)]=E[Y(0) \mid D=0, P(X)]$

Here, $D, Y(1)$ and $Y(0)$ have the same meanings as in Equation 3 and $P(X)$ is the propensity score of signing a labour contract estimated from Equation 1:

$P(X)=\operatorname{Pr}(D=1 \mid X)$

\footnotetext{
7 The conditional independence assumption assumes that potential outcomes are independent of the treatment assignment. This inevitably represents a strong assumption in labour studies using observational data (Caliendo \& Kopeinig, 2006). However, this assumption is not unreasonable in this study because in the RUMiC data, our modelling results, reported later, suggest that observed firm and job related factors are far more important than observed personal characteristics, and thus probably also unobserved personal characteristics, in explaining employee outcomes - see also Ge and Lehmann (2013) who reach the same conclusion, employing RUMiC data.
} 
Based on the covariates in Table 1, nearest neighbour, kernel, and stratification methods are used to implement propensity score matching (Becker \& Ichino, 2002).

\section{Heterogeneous treatment effect of labour contract}

A basic paradigm in the literature based on the potential outcomes model is that there can be individual heterogeneity in treatment effects, which stands in contrast to traditional regression modelling, which assumes constant parameters. Currently little attention is paid to the analysis of the heterogeneity of treatment effects in China's labour studies. This may be particularly important for migrant workers since they have a significantly lower incidence of signing labour contracts than urban workers. In particular, little is known in the existing literature as to whether a positive selection effect (ie. workers who are most likely to have a labour contract benefit most from the Labour Contract Law), a negative selection effect (ie. workers who are least likely to have a labour contract benefit most from the Labour Contract Law) or a balanced/ambiguous effect prevails in China's urban labour market.

Recognition that the treatment effect can be heterogeneous has spurned new methods for generating causal inference as well as new interpretations of extant methods. Following other studies (Brand \& Xie, 2010; Xie, 2013; Xie et al., 2012), we estimate a stratification-multilevel model of the heterogeneity of the treatment effect (HTE): ${ }^{8}$

Level 1: $\boldsymbol{Y}_{i j}=\delta_{0 j}+\delta_{1 j} \cdot$ Contract $_{i j}+\mu_{i j}$

Here $\delta_{1 j}$ is the average treatment effect of signing a labour contract on the $i$ th worker's outcome in the $j$ th stratum of the propensity score. In other words, $\delta_{l j}$ is the mean difference in outcomes between workers with, and without, a labour contract. $\mu$ is the error term. Because the treatment effect of signing a labour contract is related to the propensity to sign a labour contract, the model estimates:

Level 2: $\boldsymbol{\delta}_{1 j}=\pi_{10}+\pi_{1} \cdot$ Stratum $_{j}+\tau_{1 j}$

Here $\operatorname{Stratum}_{j}$ is the $j$ stratum of the propensity score and $\pi_{1}$ is the heterogeneous treatment effect of signing a labour contract among workers at different strata of propensity score. $\tau$ is the error term. ${ }^{9}$ The propensity score, calculated from Equation 1 , is used to construct balanced propensity score strata and, within each stratum, estimates the average treatment effect. The linear trend in treatment effects are tested by using variance-weighted least squares regression.

\section{Results}

Table 2 presents the estimates from the logit model for Equation 1. The results are generally consistent with other recent studies examining the determinants of who receives a labour contract (see eg. Cheng et al., 2014; Gallagher et al., 2013). The

\footnotetext{
${ }^{8}$ For detailed discussion of the stratification-multilevel model, see Guo and Fraser (2010) and Xie et al. (2012).

${ }^{9}$ One potential issue with the hierarchical HTE model is that there may not be enough treated cases in the lowest propensity score stratum, or enough control cases in the highest propensity score stratum, to estimate the Level-1 effect (Equation 8). To address this issue, following Xie et al. (2012), we merge small strata at the low end and high end in the analysis.
} 
results suggest that males and married migrant workers are 3 per cent and 5 per cent more likely to receive a labour contract respectively; however, gender and marital status are insignificant in the sample of urban workers. Migrant workers in poor health have a 22 per cent lower likelihood of having a labour contract while urban workers in poor health have just a 4 per cent lower likelihood of receiving a contract. Based on the marginal effects, education, work experience, occupational training and employer size are more important for migrant workers than urban workers in determining access to a labour contract. This finding is entirely consistent with that of Gallagher et al. (2013, p.15), who concluded, based on 2010 CULS data, that "treatment of migrants differs much more with individual or job characteristics than treatment of local residents". The statistically significant coefficients for education, work experience and occupational training, each of which is related to one's ability, are suggestive that signing a labour contract is not fully exogenous.

[Table 2 here]

Table 3 presents the OLS estimates for the determinants of hourly and monthly wages. Migrant workers with a labour contract receive a 12.1 per cent higher hourly wage and a 5.9 per cent higher monthly wage. Urban workers with a labour contract receive a 25.3 per cent higher hourly wage and a 23.6 per cent higher monthly wage. Cheng et al. (2014) reached mixed results for migrant workers in Guangdong province. They found that having a labour contract decreased the natural log of the monthly base wage by 5.6 per cent, but increased the natural log of hourly income (base wage plus overtime allowance) by approximately 6.7 per cent. Cui et al. (2013) found that the Labour Contract Law increased average wages in manufacturing firms by 21.6 per cent. However, because Cui et al. (2013) use firm level data, they do not estimate the effect of signing an individual labour contract on individual wages or control for schooling or experience, as is standard in a Mincer equation.

The results for the other variables (eg. schooling, experience, gender, poor health, occupational training and firm size) are consistent with previous studies for urban China and studies for other countries. One issue is that returns to schooling are endogenous. For our purposes one would be concerned if addressing this affected the coefficient on having a labour contract. To examine this issue, we used the propensity score, estimated from Equation 1, as a proxy of ability. The results are shown in appendix 1. The results show that personal ability has a statistically significant positive effect on migrant workers' hourly wage and on urban workers' monthly wage. Nonetheless, even after taking into account personal ability, having a labour contract still has the same magnitude of effect on hourly and monthly wages.

\section{[Table 3 here]}

Table 4 presents the OLS estimates for the determinants of monthly working hours. Having a labour contract reduces monthly working hours by 6 per cent for migrant workers. However, it has no significant effect among urban workers. The signs on the coefficients of most of the other variables are consistent with previous studies of the determinants of labour supply in China (see eg. Li \& Zax, 2003; Mishra \& Smyth, 2013; Smyth, Qian, Nielsen \& Kaempfer, 2013). Of note, the coefficient on monthly wages is negative and statistically significant for migrant workers, which suggests the existence of a backward bending labour supply curve. A potential concern with the 
OLS estimates is that wages are endogenous and instrumenting for wages might change the coefficient on having a labour contract. To address this issue, we instrumented for wages using the square of years of schooling and age interacted with education, which are common instrumental variables in labour supply equations (see also Mishra \& Smyth, 2013, who follow the same strategy). The results are reported in appendix 2. The coefficient on wages is now positive for migrant workers, suggesting that the substitution effect outweighs the income effect. The switch from a negative to positive coefficient on wages in the instrumental variable estimates is consistent with $\mathrm{Li}$ and $\mathrm{Zax}$ (2003). Of relevance for our purposes, though, the coefficient on having a labour contract for migrant workers in the instrumental variable estimates is identical to the OLS estimates to two decimal places.

\section{[Table 4 here]}

Table 5 presents the OLS results for the determinants of subjective wellbeing. Having a labour contract increases the GHQ-12 index by 0.35 points for migrant workers and 0.73 points for urban workers. This result is consistent with the finding in studies for other countries that having a labour contract increases subjective wellbeing (see eg. de Graf Zijl, 2005). The reasoning is that having a contract provides more job security. According to De Witte and Naswal (2003), an individual with a temporary or insecure job arrangement will experience lower subjective wellbeing because of higher job stress due to more aggravating work characteristics, asymmetrical psychological contracts or deprivation due to lack of identity with the employer. For migrant workers, having unemployment insurance and industrial injury insurance increases subjective wellbeing, while having superannuation and participating in the house provident fund decreases subjective wellbeing. To access the latter two benefits, migrant workers need to work in cities until retirement age and purchase a house, which is not feasible for the vast majority of migrant workers who will be returning to the countryside by their forties or fifties. In addition, these benefits cannot be transferred when they migrate elsewhere and the accumulative contributions to these accounts cannot be withdrawn when they return to the countryside. The results for the other variables (eg. age, education, gender, health status, income and marital status) are consistent with previous studies of the determinants of subjective wellbeing in urban China (Appleton \& Song, 2008; Knight \& Gunatilaka, 2010).

\section{[Table 5 here]}

Tables 6 and 7 present the estimates from a logit model for the probability that migrant and urban workers receive various employee benefits. Having a labour contract increases the probability of having unemployment insurance, superannuation and industrial injury insurance and participating in the housing provident fund among migrant workers by 11, 18, 18 and 5 per cent respectively and among urban workers by 37, 20, 39 and 34 per cent respectively. These results are consistent with previous studies which have found that having a labour contract increases the likelihood of participating in social insurance schemes in China (see Cheng et al., 2014; Freeman \& Li, 2013; Gallagher et al., 2013; Gao et al., 2012). The results, however, differ in terms of relative magnitude between migrant workers and urban workers from Gallagher et al (2013) who found, using 2010 CULS, that having a labour contract was a stronger predictor of participating in social insurance for migrant workers than urban workers. That the relative magnitudes differ might be explained by the fact that 
our data is for 2008 and Gallagher et al. (2013) use data for 2010. Gallagher et al (2013) found, using data from 2005 CULS, that having a labour contract was a stronger predictor of participating in social insurance for urban workers than migrant workers. If, as the findings in Gallagher et al. (2013) suggest, the Labour Contract Law magnified the effect of having a labour contract on participating in social insurance schemes for migrant workers, but reduced it for urban workers, that our data were collected soon after the legislation came into effect, might mean that not enough time had elapsed for this trend to come to the fore. The results for the control variables (eg. education, gender, work experience, marital status) are consistent with previous studies on the determinants of participation in social insurance (see eg. Cheng et al., 2014; Freeman \& Li, 2013; Gallagher et al., 2013; Gao et al., 2012; Nielsen, Nyland, Smyth, Zhang \& Zhu, 2005; Song \& Appleton, 2008).

\section{[Tables 6 and 7 here]}

Tables 8 and 9 present the ATT results for having a labour contract based on three different approaches to matching. ${ }^{10}$ For migrant workers with a labour contract, the ATT results show that the majority of the difference in outcomes is attributable to having a labour contract, relative to the counterfactual of migrant workers not having a labour contract. For example, the pre-matching differences of the natural log of the hourly wage and the natural log of the monthly wage between contracted and noncontracted migrant workers are 0.26 and 0.15 points respectively. After propensity score matching, having a labour contract increases the natural log of the hourly wage by 0.166 to 0.187 points and the natural $\log$ of the monthly wage by 0.089 to 0.094 points for a migrant worker who has a labour contract. The ATTs are smaller than the pre-matching differences, but it demonstrates that having a labour contract still has a significant effect on these outcomes after taking into account endogeneity.

The vast majority of the differences before matching in the natural log of working hours (0.09) or working hours (26.11) for migrant workers can be explained by having a labour contract according to the ATT results, suggesting that the Labour Contract Law is effective in reducing working hours among migrant workers who have a labour contract. The difference before matching in subjective wellbeing between migrants with, and without, a labour contract was 0.81 points. The ATT results suggest that having a labour contract increases subjective wellbeing of migrant workers by 0.45 to 0.52 points. The results also show that having a labour contract contributes to most of the difference in participation in all four employee benefits between contracted and non-contracted migrant workers. Having a labour contract increases the participation rate for migrant workers by $18-19$ per cent in unemployment insurance, by $25-26$ per cent in superannuation, by $24-25$ per cent in industrial injury insurance and by 11 per cent in the housing provident fund.

\footnotetext{
10 As suggested by Lechner (2002), bootstrapping was used to estimate standard errors in testing the statistical significance of treatment effects. Following existing literature (see e.g. Caliendo et al., 2008; Caliendo \& Kopeinig, 2006; Rosenbaum \& Rubin, 1983), several robustness checks (i.e. standardised bias, two-sample t-test and F-test of joint significance) of the covariate imbalance before, and after, matching were conducted. Results showed that the matching is reliable with a bias reduction below 5 per cent. The likelihood-ratio test also rejects the null hypothesis of joint insignificance of all the regressors at the 1 per cent significance level. Detailed results are available from the authors.
} 
The ATT results for urban workers show that having a labour contract contributes between 0.44 and 0.53 points in the natural log of the hourly wage, between 0.45 and 0.48 points in the natural log of the monthly wage and between 0.03 and 0.05 points difference in the natural log of monthly working hours. The ATT of having a labour contract on subjective wellbeing of urban workers (1.8-2.0) is higher than the difference before matching (1.6). Having a labour contract also contributes to the vast majority of difference in the participation of urban workers in unemployment insurance, industrial injury insurance and the house provident fund according to the results of three matching approaches. In terms of superannuation, the results of nearest neighbour matching (0.356) and stratification matching (0.341) show that the ATT of having a labour contract is higher than the difference before matching (0.3189). This result implies that the Labour Contract Law has helped to protect some urban workers who are disadvantaged or have relatively low ability in China's fast evolving labour market. As shown below, the heterogeneous treatment effects of having a labour contract among the lower strata of propensity scores are similar to, or higher than, those among the higher strata of propensity scores.

\section{[Tables 8 and 9 here]}

Tables 10 and 11 present the results of the heterogeneous treatment effects of having a labour contract by strata of propensity score (the higher the stratum, the higher the propensity to have a labour contract). For migrant workers, the treatment effect of having a labour contract on the hourly wage, monthly wage and monthly working hours mainly occur at stratum 4 or 5 and above and the effect is larger in the higher strata. Meanwhile, the treatment effect is significant for stratum 2 for the hourly wage and for strata 1-4 for the monthly working hours. On one hand, having a labour contract is more beneficial for those with a higher propensity score. For instance, the treatment effects of having a labour contract on the hourly wage and monthly wage are as high as 0.45 and 0.29 points for those in stratum 9. On the other hand, having a labour contract has some benefits for those with a lower propensity score, although the effect is sometimes quite limited. Having a labour contract has the biggest effects in improving subjective wellbeing in stratum 1 (only) and in reducing monthly working hours in stratum 4. Having a labour contract also helps to distribute the benefits more widely between strata in terms of participation in unemployment insurance, industrial injury insurance and superannuation, although it remains that the higher strata still benefit more than those in the lower strata. In terms of participation in the housing dividend fund, the treatment effects are only statistically significant at stratum 5 and above. In sum, among migrant workers, having a labour contract has a generally positive selection effect in determining wages and access to employee benefits, a relatively balanced effect in determining monthly working hours and a limited negative selection effect in determining subjective wellbeing.

Among urban workers, the treatment effects on hourly wage and monthly wages are more widely distributed than among migrant workers. Most of the strata benefit from having a labour contract. In contrast to the results for migrant workers, the largest treatment effects do not occur at the highest stratum, but in the lower or upper-middle strata, such as stratum 1 (eg. 0.485 in hourly wage and 0.585 in monthly wage) and stratum 10 (eg. 0.620 in hourly wage, 0.537 in monthly wage and 4.26 in subjective wellbeing). Having a labour contract helps distribute the benefits more widely between strata for participation in social insurance and the housing provident fund. In 
general, among urban workers, having a labour contract has a relatively balanced effect in determining wages and access to employee benefits and a (limited) positive selection effect in determining monthly working hours and subjective wellbeing.

Overall, the results show that having a labour contract has different patterns of heterogeneous treatment effects on the two groups. This demonstrates the existence of labour market segregation in urban China. Having a labour contract helps increase wages, reduce working hours and improve access to employee benefits for migrant workers. In particular, it has a relatively balanced effect across stratum in reducing migrant workers' working hours and improving their access to the three social insurance schemes. In the longer term, this is likely to spill over to a broader set of outcomes and help break down segregation of the labour market.

[Tables 10 and 11 here]

\section{Conclusion}

In this study we have examined how having a labour contract affects a number of employee outcomes for migrant and urban workers. This study improves on other recent studies examining the impact of the Labour Contract Law in China in that we examine a broader range of outcomes for employees and specifically address the causal effect of having a labour contract on a range of employee outcomes using propensity score matching. Initial academic comment on the effectiveness of the new legislation was sceptical. Zheng (2009) argued that the legislation was likely to be ineffective because it would not be adequately enforced. The onset of the Global Financial Crisis in 2008 perpetuated concerns that the state would side with the interests of capital in terms of taking a lax approach to enforcement (Freeman \& $\mathrm{Li}$, 2013). Early evaluations, based on case studies, were not encouraging. These studies generally suggested that the legislation had little, or no, effect on improving employee benefits (see eg. Chan, 2009). More recent studies, using a range of datasets, suggest that having a labour contract is positively correlated with various employee outcomes (Cheng et al., 2014; Cui et al., 2013; Freeman \& Li, 2013; Gallagher et al. 2013; Gao et al 2012; Wang et al, 2013). What is striking about our results is that the ATT and HTE results suggest that the effect of having a labour contract on myriad employee outcomes is generally much larger than previous studies have found.

The effectiveness of the Labour Contract Law is an important public policy issue in China. The advocates of the legislation see enhancing job security as a valuable public good to be pursued in tandem with business laws strengthening property rights (Freeman \& Li, 2013). Our results suggest that despite the generally poor enforcement of laws in China, the Labour Contract Law is realizing its objectives in terms of improving employee outcomes, at least in the major migration destinations which are represented in the RUMiC dataset. Previous studies have highlighted the distributional consequences of the Labour Contract Law. Tang and Zhao (2009) argued that the legislation would benefit skilled workers at the expense of low-skilled workers. Cui et al. (2013) found evidence in support of this proposition. While we also find that the effect of the law is not homogenous across those with different abilities and skills, particularly for migrant workers, the heterogeneous treatment effects suggest that the Labour Contract Law has assisted urban workers who are disadvantaged in the labour market. This is reflected in the fact that the heterogeneous 
treatment effects of having a labour contract among the lower strata of propensity scores are equivalent or better than those among the higher strata of propensity scores.

One of the limitations of the findings is that they say nothing about what has happened since 2008. Gallagher et al. (2013), using 2010 CULS data, also draw rosy conclusions about the effect of the Labour Contract Law on employee outcomes. However, as Gallagher et al (2013) note, robust labour growth in urban China has facilitated implementation of the legislation. Because labour demand has been strong, employers have had to offer good conditions, including labour contracts, to attract workers. This has allowed the government to adopt a bullish approach to enforcing the new law without facing reprisal redundancies from firms. In addition, and also noted by Gallagher et al. (2013), in most cases, the requirement to offer open-ended contracts has not become binding on employers. One response by employers to the legislation was to increase the use of subcontracting. New provisions to the legislation, introduced in 2012, have made it more difficult for firms to sidestep the legislation using subcontracted labour. It remains to be seen how employers will react when the open-ended contract and subcontracting provisions become a binding constraint on employers. This suggests the need for further studies examining the effect of the legislation on employee benefits and employment using more recent data.

\section{References}

Ahsan, A. \& Pages, C. (2009). Are All Labor Regulations Equal? Evidence from Indian Manufacturing. Journal of Comparative Economics, 37(1), 62-75.

Akay, A, Giulietti, C, Robalino, J D, \& Zimmermann, K F. (2013). Remittances and Well-Being among Rural-to-Urban Migrants in China. Review of Economics of the Household (in press).

Alvarez, F. \& Veracierto, M. (1998). Search, Self-insurance and Job Security Provisions. Federal Reserve Bank of Chicago Working Paper 98-2.

Appleton, S. \& Song, L. (2008). Life Satisfaction in Urban China: Components and Determinants. World Development, 36, 2325-234

Becker, J \& Elfstrom, M. (2010). The Impact of China's Labor Contract Law on Workers. International Labor Rights Forum.

Bentolila, S. \& Bertola, G. (1990). Firing Costs and Labor Demand: How Bad is Eurosclerosis? Review of Economic Studies, 57, 381-402.

Besley, T \& Burgess, R. (2004). Can Labor Regulation Hinder Economic Performance? Evidence from India. Quarterly Journal of Economics, 119(1), 91-134.

Brand, J E, \& Xie, Y. (2010). Who Benefits Most from College? Evidence for Negative Selection in Heterogeneous Economic Returns to Higher Education. American Sociological Review, 75(2), 273-302.

Chan, J. (2009). Meaningful Progress or Illusory Reform? Analysing China's Labour Contract Law. New Labor Forum, 18(2), 43-51.

Caliendo, M, Hujer, R, \& Thomsen, S L. (2008). The Employment Effects of JobCreation Schemes in Germany: A Microeconometric Evaluation. In T. Fomby, R. C. Hill, D. L. Millimet, J. A. Smith \& E. J. Vytlacil (Eds.), Modelling and Evaluating Treatment Effects in Econometrics (pp. 381-428). Bingley: Emerald. 
Caliendo, M, \& Kopeinig, S. (2006). Some Practical Guidance for the Implementation of Propensity Score Matching Estimators. Journal of Economic Surveys, 22(1), 31-72.

Chen, Y-F, \& Funke, M. (2009). China's New Labour Contract Law: No Harm to Employment? China Economic Review, 20(3), 558-572.

Cheng, Y. \& Yang, L. (2010). The Impact of Labour Contract Law's Enforcement on Chinese Enterprises' Human Resources Management - Based on the Perspective of HR Managers. Economic Theory and Business Management, 7, 66-73.

Cheng, Z, Nielsen, I, \& Smyth, R. (2014). Access to Social Insurance in Urban China: A Comparative Study of Rural-Urban and Urban-Urban Migrants in Beijing. Habitat International, 41, 243-252.

Cheng, Z, Wang, H, \& Chen, Y. (2014). Labour Contract, Trade Union Membership, and Workplace Relations: A Study of Migrant Workers in Guangdong Province, China. In Z. Hao \& S. Chen (Eds.), Social Issues in China: Gender, Ethnicity, Labor, and the Environment (pp. 183-206). New York: Springer.

Clark, A. \& Oswald, A. (1994). Unhappiness and unemployment. The Economic Journal, 104 (424), 648-659.

Clark, A. and A. Oswald (2002). A simple statistical method for measuring how life event affect happiness. International Journal of Epidemiology, 31 (6), 11391144.

Cooney, S., Biddulph, S., Li, K. and Zhu, Y. (2007). China's New Labour Contract Law: Responding to the Growing Complexity of Labour Relations in the PRC. UNSW Law Journal, 30(3), 786-801.

Cui, F, Ge, Y, \& Jing, F. (2013). The Effects of the Labor Contract Law on the Chinese Labor Market. Journal of Empirical Legal Studies, 10(3), 462-483.

De Graaf-Zijl, M. (2005). The Anatomy of Job Satisfaction and the Role of Contingent Employment Contracts. Tinbergen Institute Discussion Papers TI2005-119/3.

De Witte, H. \& Naswal, K. (2003). 'Objective' vs 'Subjective' Job Insecurity: Consequences of Temporary Work for Job Satisfaction and Organizational Commitment in European Countries. Economic and Industrial Democracy, 24(2), 149-188.

Dehejia, R. (2005). Practical Propensity Score Matching: A Reply to Smith and Todd. Journal of Econometrics, 125(1-2), 355-364.

Dehejia, R H, \& Wahba, S. (2002). Propensity Score-Matching Methods for Nonexperimental Causal Studies. The Review of Economics and Statistics, 84(1), 151-161.

Ferrer-i-Carbonell, A. \& Frijters, P. (2004). How Important is Methodology for the Estimates of the Determinants of Happiness? Economic Journal, 114, 641659.

Freeman, R. \& Li, X. (2013). How Does China's New Labor Contract Law Affect Floating Workers? NBER Working Paper 19254.

Friedman, E. \& Lee, C.K. (2010). Remaking the World of Chinese Labour: A 30-Year Retrospective. British Journal of Industrial Relations, 48(3), 507-533.

Friedman, J. (2013), The Relationships Between the Housing Arrangements and Subjective Wellbeing of Rural-to-Urban Migrants in China. 
http://www.iza.org/conference_files/AMM_2013/friedman_j8892.pdf, accessed on September 24, 2013.

Gallagher, M., Giles, J., Park, A. and Wang, M. (2013). China's 2008 Labor Contract Law: Implementation and Implications for China's Workers. World Bank Policy Research Working Paper 6542.

Gao, Q, Yang, S, \& Li, S. (2012). Labor Contracts and Social Insurance Participation among Migrant Workers in China. China Economic Review, 23(4), 1195-1205.

Ge, Y, \& Lehmann, H. (2013). The Costs of Worker Displacement in Urban Labour Markets of China. IZA Journal of Labor and Development, 2(4), 1-23.

Guo, S Y, \& Fraser, M W. (2010). Propensity Score Analysis: Statistical Methods and Applications. New York: Sage.

Heckman, J J, \& Smith, J A. (1995). Assessing the Case for Social Experiments. Journal of Economic Perspectives, 9(2), 85-110.

Knight, J. \& Gunatilaka, R. (2010). Great Expectations? The Subjective Wellbeing of Rural-urban migrants in China. World Development, 38, 113-124.

Knight, J., Song, L. \& Gunatilaka, R. (2009). Subjective Well-being and its Determinants in Rural China. China Economic Review, 20, 635-649.

Kong, S T. (2010). Rural-Urban Migration in China: Survey Design and Implementation. In X. Meng, C. Manning, S. Li \& T. N. Effendi (Eds.), The Great Migration: RuralUrban Migration in China and Indonesia (pp. 135-150). Cheltenham: Edward Elgar.

Lechner, M. (2002). Some Practical Issues in the Evaluation of Heterogeneous Labour Market Programmes by Matching Methods. Journal of the Royal Statistical Society $A, 165(1)$, 59-82.

Li, H. \& Zax. J. (2003). Labour Supply in Urban China. Journal of Comparative Economics, 31(4), 795-817.

Li, J. (2008). China's New Contract Law and Protection of Workers. Fordham International Law Journal, 32(3), 1083-1131.

Lin, Y-L. (2013). Wage Effects of Employment Protection Legislation in Taiwan. Asian Economic Journal, 27(2), 145-161.

Mishra, V. \& Smyth, R. (2013). Working Hours in Chinese Enterprises: Evidence from Matched Employer-Employee Data. Industrial Relations Journal, 44(1), 57-77.

Nielsen, I, Nyland, C, Smyth, R, Zhang, M, \& Zhu, C J. (2005). Which Rural Migrants Receive Social Insurance in Chinese Cities? Evidence from Jiangsu Survey Data. Global Social Policy, 5(3), 353-381.

OECD (2004) The OECD Employment Outlook (Paris: OECD).

Paes de Barros, R. \& Corseuil, C.H. (2004). The Impact of Regulation on Brazilian Labor Market Performance. In J. Heckman, C. Pages (Eds.), Law and Employment: Lessons from Latin America and the Caribbean (pp. 273350).Chicago: University of Chicago Press.

Rosenbaum, P R, \& Rubin, D B. (1983). The Central Role of the Propensity Score in Observational Studies for Causal Effects. Biometrika, 70(1), 41-55.

Smyth, R., Qian, X., Nielsen, I. \& Kaempfer, I. (2013). Working Hours in Supply Chain Chinese and Thai Factories: Evidence from the Fair Labor Association's Soccer Project. British Journal of Industrial Relations, 51(2), 392-408.

Song, L, \& Appleton, S. (2008). Social Protection and Migration in China: What Can Protect Migrants from Economic Uncertainty? In I. Nielsen \& R. Smyth (Eds.), 
Migration and Social Protection in China (pp. 138-154). Singapore: World Scientific.

Tang, Y.J. and Zhao, W.Y. (2009). Dual Labour Market: Dismissal, Protection and Labour Contract Law. Naikai Economic Studies 1, 122-152.

Wang, H, Guo, F, \& Cheng, Z. (2013). Discrimination in Migrant Workers' Welfare Entitlements and Benefits in Urban Labour Market: Findings from a Four-City Study in China. Population, Space and Place (in press)

Xie, Y. (2013). Population Heterogeneity and Causal Inference. Proceedings of the National Academy of Sciences of the United States of America, 110(16), 62626268.

Xie, Y, Brand, J E, \& Jann, B. (2012). Estimating Heterogeneous Treatment Effects with Observational Data. Sociological Methodology, 42(1), 314-347.

Zheng, Y. (2009). It's Not What is on Paper, But What Is In Practice: China's New Labor Contract Law. Washington University Global Studies Law Review, 8, 595-617. 


\begin{tabular}{|c|c|c|c|c|c|c|c|c|}
\hline & \multicolumn{4}{|c|}{ Migrant workers } & \multicolumn{4}{|c|}{ Urban workers } \\
\hline & \multicolumn{3}{|c|}{ Labour contract status } & \multirow[b]{2}{*}{ Difference } & \multicolumn{3}{|c|}{ Labour contract status } & \multirow[b]{2}{*}{ Difference } \\
\hline & Total & Yes & No & & Total & Yes & No & \\
\hline Hourly wage (RMB) & 6.51 & 7.08 & 5.42 & 1.66 & 14.16 & 14.77 & 8.37 & 6.40 \\
\hline Ln hourly wage & 1.74 & 1.83 & 1.57 & 0.26 & 2.36 & 2.42 & 1.78 & 0.64 \\
\hline Monthly wage (RMB) & 1414.26 & 1484.36 & 1278.98 & 205.38 & 2244.48 & 2347.08 & 1258.73 & 1088.35 \\
\hline Ln monthly wage & 7.16 & 7.21 & 7.06 & 0.15 & 7.48 & 7.54 & 6.94 & 0.60 \\
\hline Monthly working hours & 233.12 & 224.22 & 250.33 & -26.11 & 172.25 & 170.76 & 186.59 & -15.83 \\
\hline Ln monthly working hours & 5.42 & 5.38 & 5.49 & -0.09 & 5.11 & 5.11 & 5.16 & -0.05 \\
\hline Unemployment insurance (\%) & 15.36 & 22.18 & 2.19 & 19.99 & 61.82 & 66.49 & 17.16 & 49.33 \\
\hline Superannuation (\%) & 23.60 & 33.38 & 4.74 & 28.64 & 82.00 & 85.03 & 53.14 & 31.89 \\
\hline Industrial injury insurance (\%) & 23.03 & 32.31 & 5.16 & 27.15 & 53.75 & 58.21 & 11.22 & 46.99 \\
\hline Housing provident fund (\%) & 9.20 & 13.29 & 1.30 & 11.99 & 54.27 & 59.16 & 7.59 & 51.57 \\
\hline General Health Questionnaire 12 (GHQ-12) index (0-36) & 28.37 & 28.64 & 27.83 & 0.81 & 28.57 & 28.72 & 27.12 & 1.60 \\
\hline Male $(\%)$ & 60.56 & & & & 56.28 & & & \\
\hline Age (years) & 29.88 & & & & 40.15 & & & \\
\hline Married (no=1, yes=1) $(\%)$ & 53.80 & & & & 84.03 & & & \\
\hline Poor health $(\mathrm{no}=1$, yes $=1)(\%)$ & 1.21 & & & & 1.89 & & & \\
\hline Schooling (years) & 9.39 & & & & 12.32 & & & \\
\hline Work experience (years) & 3.96 & & & & 13.08 & & & \\
\hline Has labour contract $(\mathrm{no}=1$, yes $=1)(\%)$ & 65.84 & & & & 90.52 & & & \\
\hline Received occupational training $(\mathrm{no}=1$, yes $=1)(\%)$ & 25.87 & & & & 36.86 & & & \\
\hline \multicolumn{9}{|l|}{ Employer size (\%) } \\
\hline More than 50 employees ( $\mathrm{no}=1$, yes $=1$ ) & 49.94 & & & & 64.97 & & & \\
\hline \multicolumn{9}{|l|}{ Employer ownership (\%) } \\
\hline SOE/COE/government agency and affiliate & 15.77 & & & & 65.46 & & & \\
\hline Private-owned, foreign-owned and joint-venture & 61.84 & & & & 25.38 & & & \\
\hline Micro-entrepreneur (getihu) and others & 22.39 & & & & 9.16 & & & \\
\hline \multicolumn{9}{|l|}{ Employer sector (\%) } \\
\hline Manufacturing & 25.12 & & & & 19.29 & & & \\
\hline Construction & 12.60 & & & & 3.43 & & & \\
\hline Wholesale and retail services & 15.58 & & & & 9.84 & & & \\
\hline Hotel and catering services & 18.82 & & & & 2.92 & & & \\
\hline Others & 27.88 & & & & 64.51 & & & \\
\hline \multicolumn{9}{|l|}{ Employer subsidy (\%) } \\
\hline Meals $($ no $=1$, yes $=1)$ & 70.20 & & & & 34.21 & & & \\
\hline Housing $(\mathrm{no}=1$, yes $=1)$ & 64.41 & & & & 3.11 & & & \\
\hline \multicolumn{9}{|l|}{ Region (\%) } \\
\hline South (Guangdong) & 23.50 & & & & 15.62 & & & \\
\hline East (Shanghai, Jiangsu, Zhejiang) & 35.70 & & & & 34.27 & & & \\
\hline Central and west (Hubei, Henan, Anhui, Chongqing, Sichuan) & 40.80 & & & & 50.12 & & & \\
\hline
\end{tabular}


Table 2 Access to labour contract (logit regression)

\begin{tabular}{|c|c|c|c|c|c|c|}
\hline & \multicolumn{3}{|c|}{ Migrant workers } & \multicolumn{3}{|c|}{ Urban workers } \\
\hline & Coefficient & & Marginal effect & Coefficient & & Marginal effect \\
\hline Male & $0.159 * *$ & $(2.23)$ & 0.0346 & 0.0659 & $(0.66)$ & 0.0028 \\
\hline Married & $0.240 * * *$ & (3.19) & 0.0520 & -0.142 & $(-1.05)$ & -0.0058 \\
\hline Poor health & $-0.930 * * *$ & $(-3.13)$ & -0.2233 & $-0.644 * *$ & $(-2.17)$ & -0.0367 \\
\hline Schooling & $0.0914 * * *$ & $(6.14)$ & 0.0198 & $0.157 * * *$ & $(9.20)$ & 0.0067 \\
\hline Work experience & $0.0405 * *$ & $(2.16)$ & 0.0088 & $0.134 * * *$ & $(10.22)$ & 0.0057 \\
\hline Work experience ${ }^{2}$ & $-0.00225^{* *}$ & $(-2.37)$ & -0.0005 & $-0.00209 * * *$ & $(-6.22)$ & -0.0001 \\
\hline Received occupational training & $0.323 * * *$ & $(4.05)$ & 0.0678 & $0.465 * * *$ & $(3.99)$ & 0.0189 \\
\hline Employer has more than 50 employees & $0.576 * * *$ & $(7.50)$ & 0.1241 & $0.986 * * *$ & $(9.09)$ & 0.0494 \\
\hline \multicolumn{7}{|c|}{ Employer ownership (ref: micro-entrepreneur and others) } \\
\hline SOE/COE/government agency and affiliate & $0.993 * * *$ & $(8.46)$ & 0.1846 & $1.370 * * *$ & $(10.37)$ & 0.0747 \\
\hline Private-owned, foreign-owned and joint-venture & $0.675 * * *$ & $(8.30)$ & 0.1493 & $0.758 * * *$ & $(5.76)$ & 0.0277 \\
\hline \multicolumn{7}{|l|}{ Employment sector (ref: others) } \\
\hline Manufacturing & $0.231 * *$ & $(2.14)$ & 0.0489 & -0.00887 & $(-0.06)$ & 0.0004 \\
\hline Construction & $-0.826 * * *$ & $(-6.93)$ & -0.1936 & $-0.699 * * *$ & $(-3.00)$ & -0.0405 \\
\hline Wholesale and retail services & -0.0490 & $(-0.47)$ & -0.0107 & $-0.278 * *$ & $(-2.00)$ & -0.0131 \\
\hline Hotel and catering services & $-0.294 * * *$ & $(-2.96)$ & -0.0656 & -0.168 & $(-0.72)$ & -0.0077 \\
\hline Meals & $0.350 * * *$ & $(4.36)$ & 0.0776 & $0.508 * * *$ & $(3.89)$ & 0.0203 \\
\hline Housing & 0.0537 & $(0.70)$ & 0.0117 & 0.206 & $(0.57)$ & 0.0069 \\
\hline \multicolumn{7}{|l|}{ Region (ref: south) } \\
\hline East & $0.391 * * *$ & $(4.11)$ & 0.0828 & $0.348 * *$ & $(2.37)$ & 0.0142 \\
\hline Central and west & $-0.351 * * *$ & $(-3.95)$ & -0.0767 & -0.00277 & $(-0.02)$ & -0.0001 \\
\hline Constant & $-1.500 * * *$ & $(-7.39)$ & & $-2.070 * * *$ & $(-7.43)$ & \\
\hline $\mathrm{N}$ & 4756 & & & 6241 & & \\
\hline Pseudo $\mathrm{R}^{2}$ & 0.1109 & & & 0.2452 & & \\
\hline
\end{tabular}

$z$ statistics in parentheses

${ }^{*} p<0.10,{ }^{* *} p<0.05,{ }^{* * *} p<0.01$ 
Table 3 Wage of migrant and urban workers (OLS regression)

\begin{tabular}{|c|c|c|c|c|c|c|c|c|}
\hline \multirow[b]{3}{*}{ Male } & \multicolumn{4}{|c|}{ Migrant workers } & \multicolumn{4}{|c|}{ Urban workers } \\
\hline & \multicolumn{2}{|c|}{ Ln hourly wage } & \multicolumn{2}{|c|}{ Ln monthly wage } & \multicolumn{2}{|c|}{ Ln hourly wage } & \multicolumn{2}{|c|}{ Ln monthly wage } \\
\hline & $0.0814 * * *$ & $(6.07)$ & $0.124 * * *$ & $(11.09)$ & $0.181 * * *$ & $(11.35)$ & $0.218 * * *$ & $(15.22)$ \\
\hline Married & -0.0151 & $(-1.07)$ & 0.00763 & $(0.65)$ & $0.0797 * * *$ & $(3.45)$ & $0.0863 * * *$ & $(4.14)$ \\
\hline Poor health & $-0.133 * *$ & $(-2.28)$ & $-0.125 * * *$ & $(-2.58)$ & $-0.246 * * *$ & $(-4.21)$ & $-0.226 * * *$ & $(-4.33)$ \\
\hline Schooling & $0.0496 * * *$ & $(17.75)$ & $0.0355 * * *$ & $(15.25)$ & $0.0564 * * *$ & $(22.55)$ & $0.0522 * * *$ & $(23.15)$ \\
\hline Work experience & $0.0495 * * *$ & $(13.90)$ & $0.0412 * * *$ & $(13.88)$ & $0.0237 * * *$ & $(9.75)$ & $0.0250 * * *$ & $(11.42)$ \\
\hline Work experience ${ }^{2}$ & $-0.00162 * * *$ & $(-8.90)$ & $-0.00131 * * *$ & $(-8.58)$ & $-0.000375 * * *$ & $(-5.85)$ & $-0.000475 * * *$ & $(-8.24)$ \\
\hline Has labour contract & $0.121 * * *$ & $(8.55)$ & $0.0590 * * *$ & $(5.03)$ & $0.253 * * *$ & $(8.72)$ & $0.236 * * *$ & $(8.99)$ \\
\hline Received occupational training & $0.0601 * * *$ & $(4.11)$ & $0.0703 * * *$ & $(5.78)$ & $0.0898 * * *$ & $(5.48)$ & $0.0872 * * *$ & $(5.89)$ \\
\hline Employer has more than 50 employees & $0.0645^{* * *}$ & $(4.37)$ & 0.00854 & $(0.70)$ & $0.165 * * *$ & $(9.27)$ & $0.180 * * *$ & $(11.22)$ \\
\hline \multicolumn{9}{|c|}{ Employer ownership (ref: micro-entrepreneur and others) } \\
\hline SOE/COE/government agency and affiliate & $0.0852 * * *$ & $(3.84)$ & 0.0135 & $(0.73)$ & $0.133 * * *$ & $(4.41)$ & $0.0552 * *$ & $(2.03)$ \\
\hline Private-owned, foreign-owned and joint-venture & $0.0539 * * *$ & $(3.24)$ & 0.0116 & $(0.84)$ & $0.165 * * *$ & $(5.28)$ & $0.126 * * *$ & $(4.46)$ \\
\hline \multicolumn{9}{|l|}{ Employment sector (ref: others) } \\
\hline Manufacturing & $0.0441 * *$ & $(2.31)$ & $0.0308 *$ & $(1.94)$ & $-0.180 * * *$ & $(-8.62)$ & $-0.161 * * *$ & $(-8.55)$ \\
\hline Construction & $0.145^{* * *}$ & $(6.18)$ & $0.187 * * *$ & $(9.61)$ & -0.0675 & $(-1.57)$ & -0.0196 & $(-0.50)$ \\
\hline Wholesale and retail services & 0.00614 & $(0.30)$ & 0.0160 & $(0.95)$ & $-0.109 * * *$ & $(-3.96)$ & $-0.0944 * * *$ & $(-3.81)$ \\
\hline Hotel and catering services & $-0.0767 * * *$ & $(-3.95)$ & $-0.0542 * * *$ & $(-3.35)$ & $-0.183 * * *$ & $(-3.85)$ & $-0.152 * * *$ & $(-3.53)$ \\
\hline Meals & -0.0159 & $(-1.03)$ & -0.00957 & $(-0.74)$ & $0.175^{* * *}$ & $(9.94)$ & $0.193 * * *$ & $(12.12)$ \\
\hline Housing & $-0.0759 * * *$ & $(-5.19)$ & $-0.0344 * * *$ & $(-2.83)$ & 0.0399 & $(0.88)$ & 0.0339 & $(0.83)$ \\
\hline \multicolumn{9}{|l|}{ Region (ref: south) } \\
\hline East & 0.0225 & $(1.31)$ & $0.0276^{*}$ & $(1.93)$ & $-0.312 * * *$ & $(-12.86)$ & $-0.312 * * *$ & $(-14.25)$ \\
\hline Central and west & $-0.330 * * *$ & $(-19.54)$ & $-0.269 * * *$ & $(-19.10)$ & $-0.648 * * *$ & $(-28.68)$ & $-0.612 * * *$ & $(-29.98)$ \\
\hline Constant & $1.094 * * *$ & $(28.48)$ & $6.671 * * *$ & $(208.69)$ & $1.228 * * *$ & $(24.69)$ & $6.417 * * *$ & (142.84) \\
\hline $\mathrm{N}$ & 4733 & & 4754 & & 6201 & & 6230 & \\
\hline Adjusted $\mathrm{R}^{2}$ & 0.318 & & 0.298 & & 0.334 & & 0.359 & \\
\hline
\end{tabular}

$t$ statistics in parentheses

* $p<0.10,{ }^{* *} p<0.05,{ }^{* * *} p<0.01$ 
Table 4 Monthly working hours of migrant and urban workers (OLS regression)

\begin{tabular}{|c|c|c|c|c|}
\hline \multirow[b]{3}{*}{ Ln monthly wage } & \multicolumn{4}{|c|}{ Ln monthly working hours } \\
\hline & \multicolumn{2}{|c|}{ Migrant workers } & \multicolumn{2}{|c|}{ Urban workers } \\
\hline & $-0.0225^{* *}$ & $(-2.48)$ & 0.00577 & $(0.92)$ \\
\hline Schooling & $-0.0133 * * *$ & $(-8.93)$ & $-0.00450 * * *$ & $(-3.90)$ \\
\hline Work experience & $-0.00739 * * *$ & $(-3.91)$ & 0.00131 & $(1.20)$ \\
\hline Work experience ${ }^{2}$ & $0.000291 * * *$ & $(3.04)$ & $-0.0000951 * * *$ & $(-3.34)$ \\
\hline Male & $0.0459 * * *$ & $(6.49)$ & $0.0356^{* * *}$ & $(4.96)$ \\
\hline Married & $0.0223 * * *$ & $(3.04)$ & 0.00678 & $(0.66)$ \\
\hline Poor health & 0.00433 & $(0.14)$ & 0.0303 & $(1.17)$ \\
\hline Has labour contract & $-0.0597 * * *$ & $(-8.12)$ & -0.0199 & $(-1.54)$ \\
\hline Received occupational training & 0.0111 & $(1.45)$ & -0.00679 & $(-0.93)$ \\
\hline Employer has more than 50 employees & $-0.0557 * * *$ & $(-7.26)$ & 0.0118 & $(1.48)$ \\
\hline \multicolumn{5}{|c|}{ Employer ownership (ref: micro-entrepreneur and others) } \\
\hline SOE/COE/government agency and affiliate & $-0.0715 * * *$ & $(-6.19)$ & $-0.0758 * * *$ & $(-5.68)$ \\
\hline Private-owned, foreign-owned and joint-venture & $-0.0415 * * *$ & $(-4.81)$ & $-0.0374 * * *$ & $(-2.69)$ \\
\hline \multicolumn{5}{|l|}{ Employment sector (ref: others) } \\
\hline Manufacturing & -0.0125 & $(-1.26)$ & $0.0221 * *$ & $(2.37)$ \\
\hline Construction & $0.0480 * * *$ & $(3.90)$ & $0.0470 * *$ & $(2.46)$ \\
\hline Wholesale and retail services & 0.0104 & $(0.99)$ & 0.0179 & $(1.47)$ \\
\hline Hotel and catering services & $0.0216 * *$ & $(2.14)$ & 0.0312 & (1.47) \\
\hline Meals & 0.00562 & $(0.70)$ & $0.0172 * *$ & (2.18) \\
\hline Housing & $0.0396 * * *$ & (5.19) & -0.00713 & $(-0.36)$ \\
\hline \multicolumn{5}{|l|}{ Region (ref: south) } \\
\hline East & 0.00603 & $(0.67)$ & 0.00344 & $(0.31)$ \\
\hline Central and west & $0.0553 * * *$ & $(6.06)$ & $0.0403^{* * *}$ & $(3.77)$ \\
\hline Constant & $5.728 * * *$ & $(89.88)$ & $5.150 * * *$ & $(112.66)$ \\
\hline $\mathrm{N}$ & 4734 & & 6201 & \\
\hline Adjusted $\mathrm{R}^{2}$ & 0.143 & & 0.028 & \\
\hline
\end{tabular}

$t$ statistics in parentheses

$p<0.10,{ }^{* * *} p<0.05,{ }^{* * *} p<0.01$ 
Table 5 Subjective wellbeing among migrant and urban workers (OLS regression)

\begin{tabular}{|c|c|c|c|c|}
\hline \multirow{2}{*}{ Ln hourly wage } & \multicolumn{2}{|c|}{ Migrant workers } & \multicolumn{2}{|c|}{ Urban workers } \\
\hline & $0.544 * * *$ & $(3.30)$ & $0.717 * * *$ & $(5.69)$ \\
\hline Schooling & $0.203 * * *$ & $(6.39)$ & $0.0553 * *$ & $(2.11)$ \\
\hline Age & -0.0651 & $(-1.33)$ & $-0.215^{* * *}$ & $(-3.10)$ \\
\hline $\mathrm{Age}^{2}$ & 0.000929 & $(1.43)$ & $0.00214 * * *$ & $(2.62)$ \\
\hline Work experience & $-0.0924 * *$ & $(-2.35)$ & 0.00263 & $(0.11)$ \\
\hline Work experience ${ }^{2}$ & $0.00327 *$ & $(1.68)$ & 0.0000106 & $(0.02)$ \\
\hline Male & $0.749 * * *$ & $(5.10)$ & $0.652 * * *$ & $(4.22)$ \\
\hline Married & $0.860 * * *$ & $(4.18)$ & $0.496^{*}$ & $(1.87)$ \\
\hline Poor health & $-3.027 * * *$ & $(-4.64)$ & $-4.892 * * *$ & $(-9.33)$ \\
\hline Has labour contract & $0.384 * *$ & $(2.47)$ & $0.728 * *$ & $(2.57)$ \\
\hline Has unemployment insurance & $0.935 * * *$ & $(3.14)$ & 0.103 & $(0.48)$ \\
\hline Has superannuation & $-0.860 * * *$ & $(-3.31)$ & -0.286 & $(-1.24)$ \\
\hline Has industrial injury insurance & $1.054 * * *$ & $(4.24)$ & 0.235 & $(1.17)$ \\
\hline Has house provident fund & $-1.232 * * *$ & $(-4.05)$ & 0.0879 & $(0.45)$ \\
\hline Received occupational training & 0.217 & $(1.39)$ & $-0.399 * *$ & $(-2.57)$ \\
\hline Employer has more than 50 employees & 0.0224 & $(0.14)$ & -0.00925 & $(-0.05)$ \\
\hline \multicolumn{5}{|c|}{ Employer ownership (ref: micro-entrepreneur and others) } \\
\hline SOE/COE/government agency and affiliate & -0.152 & $(-0.73)$ & 0.334 & $(1.17)$ \\
\hline Private-owned, foreign-owned and joint-venture & 0.228 & $(0.90)$ & $0.501 *$ & $(1.66)$ \\
\hline \multicolumn{5}{|l|}{ Employment sector (ref: others) } \\
\hline Manufacturing & -0.152 & $(-0.73)$ & -0.238 & $(-1.17)$ \\
\hline Construction & 0.228 & $(0.90)$ & -0.0609 & $(-0.14)$ \\
\hline Wholesale and retail services & 0.325 & $(1.48)$ & -0.321 & $(-1.18)$ \\
\hline Hotel and catering services & 0.242 & $(1.16)$ & -0.650 & $(-1.39)$ \\
\hline Meals & 0.0417 & $(0.25)$ & $-0.296^{*}$ & $(-1.72)$ \\
\hline Housing & 0.134 & $(0.83)$ & $-0.793 *$ & $(-1.83)$ \\
\hline \multicolumn{5}{|l|}{ Region (ref: south) } \\
\hline East & $-0.460 * *$ & $(-2.43)$ & $1.492 * * *$ & $(6.41)$ \\
\hline Central and west & -0.146 & $(-0.77)$ & $1.624 * * *$ & (7.08) \\
\hline Constant & $25.51 * * *$ & $(28.89)$ & $28.64 * * *$ & $(19.75)$ \\
\hline $\mathrm{N}$ & 4210 & & 3693 & \\
\hline Adjusted $\mathrm{R}^{2}$ & 0.049 & & 0.075 & \\
\hline
\end{tabular}


Table 6 Access to social insurance among migrant workers (logit regression)

\begin{tabular}{|c|c|c|c|c|c|c|c|c|c|c|c|c|}
\hline \multirow[b]{3}{*}{ Schooling } & \multicolumn{3}{|c|}{ Unemployment insurance } & \multicolumn{3}{|c|}{ Superannuation } & \multicolumn{3}{|c|}{ Industrial injury insurance } & \multicolumn{3}{|c|}{ House provident fund } \\
\hline & \multirow{2}{*}{$\begin{array}{c}\text { Coefficient } \\
0.0934^{* * *}\end{array}$} & \multicolumn{2}{|c|}{ Marginal effect } & \multirow{2}{*}{$\begin{array}{c}\text { Coefficient } \\
0.109^{* * *}\end{array}$} & \multicolumn{2}{|c|}{ Marginal effect } & \multirow{2}{*}{$\begin{array}{c}\text { Coefficient } \\
0.0770^{* * * *}\end{array}$} & \multicolumn{2}{|c|}{ Marginal effect } & \multirow{2}{*}{$\frac{\text { Coefficient }}{0.0639^{* * *}}$} & \multicolumn{2}{|c|}{ Marginal effect } \\
\hline & & $(7.76)$ & 0.0139 & & $(10.03)$ & 0.0260 & & $(7.20)$ & 0.0186 & & $(4.64)$ & 0.0056 \\
\hline Work experience & $0.115^{* * * *}$ & (7.04) & 0.0171 & $0.0978 * * *$ & $(6.79)$ & 0.0232 & $0.0885^{* * *}$ & (6.31) & 0.0214 & $0.0852 * * *$ & (4.57) & 0.0075 \\
\hline Work experience $^{2}$ & $-0.00432 * * *$ & $(-4.77)$ & -0.0006 & $-0.00339 * * *$ & $(-4.30)$ & -0.0008 & $-0.00331 * * *$ & $(-4.39)$ & -0.0008 & $-0.00311 * * *$ & $(-3.01)$ & -0.0003 \\
\hline Male & $-0.0929 *$ & $(-1.69)$ & -0.0140 & -0.00537 & $(-0.11)$ & -0.0013 & 0.0685 & (1.37) & 0.0164 & 0.0207 & $(0.32)$ & 0.0018 \\
\hline Married & $0.110^{*}$ & $(1.87)$ & 0.0163 & $0.179 * * *$ & $(3.37)$ & 0.0424 & $0.110^{* *}$ & $(2.08)$ & 0.0264 & -0.0196 & $(-0.29)$ & -0.0017 \\
\hline Poor health & -0.643 & $(-1.40)$ & -0.0605 & -0.167 & $(-0.60)$ & -0.0364 & -0.444 & $(-1.45)$ & -0.0846 & -- & -- & -- \\
\hline Has labour contract & 0.916 *** & (11.10) & 0.1149 & $0.892 * * *$ & (13.71) & 0.1834 & $0.854 * * *$ & $(13.45)$ & 0.1798 & $0.726 * * *$ & (7.31) & 0.0541 \\
\hline Received occupational training & -0.0841 & $(-1.43)$ & -0.0122 & $0.114 * *$ & $(2.18)$ & 0.0278 & $0.137 * * *$ & $(2.65)$ & 0.0341 & -0.0666 & $(-0.98)$ & -0.0057 \\
\hline Employer has more than 50 employees & $0.452 * * *$ & (7.08) & 0.0677 & $0.537 * * *$ & $(9.62)$ & 0.1275 & $0.512 * * *$ & $(9.35)$ & 0.1237 & $0.458 * * *$ & (6.03) & 0.0408 \\
\hline \multicolumn{13}{|c|}{ Employer ownership (ref: micro-entrepreneur and others) } \\
\hline SOE/COE/government agency and affiliate & $0.240 * *$ & $(2.40)$ & 0.0399 & $0.450 * * *$ & (5.18) & 0.1234 & $0.395 * * *$ & (4.51) & 0.1082 & $0.588 * * *$ & (4.89) & 0.0729 \\
\hline Private-owned, foreign-owned and joint-venture & $0.184 * *$ & $(2.17)$ & 0.0266 & $0.194 * * *$ & $(2.65)$ & 0.0451 & $0.309 * * *$ & $(4.19)$ & 0.0720 & $0.249 * *$ & (2.29) & 0.0208 \\
\hline \multicolumn{13}{|l|}{ Employment sector (ref: others) } \\
\hline Manufacturing & $0.407 * * *$ & (5.67) & 0.0696 & $0.372 * * *$ & $(5.67)$ & 0.0965 & $0.327 * * *$ & (4.99) & 0.0854 & $0.472 * * *$ & $(5.76)$ & 0.0510 \\
\hline Construction & $-0.535 * * *$ & $(-4.48)$ & -0.0599 & $-0.561 * * *$ & $(-5.68)$ & -0.1059 & -0.0834 & $(-0.94)$ & -0.0195 & $-0.620 * * *$ & $(-4.22)$ & -0.0369 \\
\hline Wholesale and retail services & -0.157 & $(-1.64)$ & -0.0217 & -0.0457 & $(-0.57)$ & -0.0107 & -0.114 & $(-1.37)$ & -0.0266 & -0.0190 & $(-0.16)$ & -0.0016 \\
\hline Hotel and catering services & -0.142 & $(-1.63)$ & -0.0199 & $-0.180 * *$ & $(-2.33)$ & -0.0404 & -0.118 & $(-1.54)$ & -0.0275 & -0.0656 & $(-0.63)$ & -0.0055 \\
\hline Meals & $0.335 * * *$ & $(4.92)$ & 0.0453 & $0.216^{* * *}$ & $(3.68)$ & 0.0489 & $0.256^{* * *}$ & $(4.41)$ & 0.0587 & $0.363 * * *$ & $(4.44)$ & 0.0281 \\
\hline Housing & -0.0716 & $(-1.18)$ & -0.0108 & -0.0137 & $(-0.25)$ & -0.0033 & 0.0895 & (1.64) & 0.0214 & -0.0654 & $(-0.93)$ & -0.0058 \\
\hline \multicolumn{13}{|l|}{ Region (ref: south) } \\
\hline East & -0.0494 & $(-0.77)$ & -0.0073 & $-0.196 * * *$ & $(-3.31)$ & -0.0453 & $-0.295 * * *$ & $(-5.01)$ & -0.0683 & $0.599 * * *$ & (7.83) & 0.0621 \\
\hline Central and west & $-0.511 * * *$ & $(-7.17)$ & -0.0721 & $-0.633 * * *$ & $(-10.04)$ & -0.1419 & $-0.707 * * *$ & $(-11.34)$ & -0.1603 & 0.0137 & $(0.16)$ & 0.0012 \\
\hline Constant & $-3.482 * * *$ & $(-18.81)$ & & $-0.254 * * *$ & $(-7.77)$ & & $-3.033 * * *$ & $(-19.03)$ & & $-3.972 * * *$ & $(-17.75)$ & \\
\hline $\begin{array}{c}\mathrm{N} \\
\text { Pseudo } \mathrm{R}^{2}\end{array}$ & $\begin{array}{l}4753 \\
0.2612 \\
\end{array}$ & & & $\begin{array}{l}4753 \\
0.2792 \\
\end{array}$ & & & $\begin{array}{r}4753 \\
0.2390 \\
\end{array}$ & & & $\begin{array}{l}4698 \\
0.2457 \\
\end{array}$ & & \\
\hline
\end{tabular}

Fifty five cases with poor health status were dropped in the house provident fund model because they predicted no access perfectly in the nonlinear logistic model. Dropping this should exert little impact on the model since poor health status is statistically insignificant in the other three models.

$z$ statistics in parentheses

$p<0.10,{ }^{* *} p<0.05,{ }^{* * *} p<0.01$ 
Table 7 Access to social insurance among urban workers (logit regression)

\begin{tabular}{|c|c|c|c|c|c|c|c|c|c|c|c|c|}
\hline \multirow[b]{3}{*}{ Schooling } & \multicolumn{3}{|c|}{ Unemployment insurance } & \multicolumn{3}{|c|}{ Superannuation } & \multicolumn{3}{|c|}{ Industrial injury insurance } & \multicolumn{3}{|c|}{ House provident fund } \\
\hline & \multirow{2}{*}{$\begin{array}{c}\text { Coefficient } \\
0.0336^{* * *}\end{array}$} & \multicolumn{2}{|c|}{ Marginal effect } & \multirow{2}{*}{$\begin{array}{r}\text { Coefficient } \\
0.0119^{*}\end{array}$} & \multicolumn{2}{|c|}{ Marginal effect } & \multirow{2}{*}{$\begin{array}{c}\text { Coefficient } \\
0.0272^{* * *}\end{array}$} & \multicolumn{2}{|c|}{ Marginal effect } & \multirow{2}{*}{$\begin{array}{c}\text { Coefficient } \\
0.0947 * * *\end{array}$} & \multicolumn{2}{|c|}{ Marginal effect } \\
\hline & & $(6.00)$ & 0.0127 & & $(1.87)$ & 0.0028 & & $(4.98)$ & 0.0108 & & $(15.19)$ & 0.0376 \\
\hline Work experience & $0.0328 * * *$ & $(6.23)$ & 0.0124 & $0.0235 * * *$ & (4.19) & 0.0056 & $0.0211 * * *$ & (4.03) & 0.0084 & $0.0701 * * *$ & (12.62) & 0.0278 \\
\hline Work experience $^{2}$ & $-0.000604 * * *$ & $(-4.38)$ & -0.0002 & $-0.000604 * * *$ & $(-4.20)$ & -0.0001 & $-0.000439 * * *$ & $(-3.22)$ & -0.0002 & $-0.00109^{* * *}$ & $(-7.54)$ & -0.0004 \\
\hline Male & -0.00803 & $(-0.23)$ & -0.0030 & -0.0546 & $(-1.36)$ & -0.0130 & $0.0896 * * *$ & $(2.58)$ & 0.0356 & $0.108 * * *$ & $(2.90)$ & 0.0428 \\
\hline Married & $-0.0970^{*}$ & $(-1.88)$ & -0.0362 & $0.114 * *$ & $(2.01)$ & 0.0282 & $-0.105^{* *}$ & $(-2.06)$ & -0.0417 & $-0.141 * * *$ & $(-2.63)$ & -0.0556 \\
\hline Poor health & -0.206 & $(-1.56)$ & -0.0798 & 0.0612 & $(0.41)$ & 0.0142 & $-0.456 * * *$ & $(-3.41)$ & -0.1787 & -0.136 & $(-0.97)$ & -0.0543 \\
\hline Has labour contract & $0.978 * * *$ & (14.07) & 0.3743 & $0.660 * * *$ & (10.58) & 0.1979 & $1.076^{* * *}$ & (13.98) & 0.3867 & $0.915 * * *$ & (10.38) & 0.3402 \\
\hline Received occupational training & $0.148^{* * *}$ & $(4.03)$ & 0.0554 & $0.175^{* * *}$ & $(4.07)$ & 0.0408 & $0.217 * * *$ & $(6.07)$ & 0.0861 & $0.215 * * *$ & $(5.62)$ & 0.0849 \\
\hline Employer has more than 50 employees & $0.299 * * *$ & (7.75) & 0.1141 & $0.163 * * *$ & $(3.75)$ & 0.0398 & $0.300 * * *$ & $(7.81)$ & 0.1190 & $0.409 * * *$ & (10.08) & 0.1619 \\
\hline \multicolumn{13}{|c|}{ Employer ownership (ref: micro-entrepreneur and others) } \\
\hline SOE/COE/government agency and affiliate & $0.277 * * *$ & $(4.15)$ & 0.1055 & $0.243 * * *$ & $(3.54)$ & 0.0601 & $0.351 * * *$ & $(5.10)$ & 0.1393 & $0.713 * * *$ & $(9.21)$ & 0.2786 \\
\hline Private-owned, foreign-owned and joint-venture & 0.0456 & $(0.65)$ & 0.0172 & 0.0801 & (1.13) & 0.0187 & $0.205 * * *$ & $(2.84)$ & 0.0809 & $0.137 *$ & (1.68) & 0.0543 \\
\hline \multicolumn{13}{|l|}{ Employment sector (ref: others) } \\
\hline Manufacturing & $0.132 * * *$ & (2.78) & 0.0492 & $0.271 * * *$ & $(4.70)$ & 0.0593 & $0.169 * * *$ & $(3.68)$ & 0.0666 & $-0.115 * *$ & $(-2.39)$ & -0.0459 \\
\hline Construction & -0.0761 & $(-0.80)$ & -0.0290 & -0.00723 & $(-0.07)$ & -0.0017 & -0.0520 & $(-0.55)$ & -0.0207 & $-0.366 * * *$ & $(-3.59)$ & -0.1447 \\
\hline Wholesale and retail services & 0.0489 & $(0.80)$ & 0.0184 & -0.0381 & $(-0.57)$ & -0.0092 & -0.0693 & $(-1.14)$ & -0.0276 & $-0.221 * * *$ & $(-3.39)$ & -0.0879 \\
\hline Hotel and catering services & -0.122 & $(-1.12)$ & -0.0469 & $-0.301 * * *$ & $(-2.72)$ & -0.0819 & -0.0117 & $(-0.11)$ & -0.0047 & $-0.256 * *$ & $(-2.15)$ & -0.1017 \\
\hline Meals & $0.179 * * *$ & $(4.50)$ & 0.0668 & $0.180 * * *$ & $(3.84)$ & 0.0417 & $0.166^{* * *}$ & $(4.32)$ & 0.0656 & $0.342 * * *$ & $(8.26)$ & 0.1343 \\
\hline Housing & -0.0352 & $(-0.35)$ & -0.0134 & -0.0173 & $(-0.15)$ & -0.0041 & 0.131 & $(1.31)$ & 0.0517 & -0.171 & $(-1.63)$ & -0.0681 \\
\hline \multicolumn{13}{|l|}{ Region (ref: south) } \\
\hline East & $0.394 * * *$ & $(7.26)$ & 0.1446 & $0.341 * * *$ & $(5.45)$ & 0.0771 & -0.0149 & $(-0.28)$ & -0.0059 & $0.416 * * *$ & (7.30) & 0.1626 \\
\hline Central and west & $-0.239 * * *$ & $(-4.82)$ & -0.0899 & $-0.132 * *$ & $(-2.41)$ & -0.0315 & $-0.569 * * *$ & $(-11.34)$ & -0.2233 & 0.0724 & (1.36) & 0.0288 \\
\hline Constant & $-1.680 * * *$ & $(-14.49)$ & & $-0.437 * * *$ & $(-3.70)$ & & $-1.687 * * *$ & $(-14.06)$ & & $-3.524 * * *$ & $(-24.75)$ & \\
\hline $\begin{array}{c}\mathrm{N} \\
\text { Pseudo } \mathrm{R}^{2}\end{array}$ & $\begin{array}{r}6240 \\
0.1444\end{array}$ & & & $\begin{array}{r}6239 \\
0.1025\end{array}$ & & & $\begin{array}{r}6237 \\
0.1341\end{array}$ & & & $\begin{array}{l}6239 \\
0.2642\end{array}$ & & \\
\hline
\end{tabular}


Table 8 Average treatment effect on the treated (ATT) of labour contract among migrant workers

\begin{tabular}{|c|c|c|c|c|c|c|}
\hline & Hourly wage & Ln hourly wage & Monthly wage & $\begin{array}{l}\text { Ln monthly } \\
\text { wage }\end{array}$ & Working hours & $\begin{array}{l}\text { Ln monthly } \\
\text { working hours }\end{array}$ \\
\hline \multirow[t]{2}{*}{ Nearest neighbour matching } & $1.218 * * *$ & $0.187 * * *$ & $139.281 * * *$ & $0.089 * * *$ & $-20.648 * * *$ & $-0.075^{* * *}$ \\
\hline & $(7.620)$ & $(9.075)$ & $(4.836)$ & $(5.820)$ & $(-7.445)$ & $(-3.970)$ \\
\hline \multirow[t]{2}{*}{ Kernel matching } & $1.168 * * *$ & $0.174 * * *$ & $140.637 * * *$ & $0.094 * * *$ & $-18.953 * * *$ & $-0.078 * * *$ \\
\hline & $(11.142)$ & $(9.584)$ & $(11.762)$ & $(11.034)$ & $(-10.816)$ & $(-7.526)$ \\
\hline \multirow{3}{*}{ Stratification matching } & $1.100 * * *$ & $0.166 * * *$ & $127.831 * * *$ & $0.084 * * *$ & $-19.119 * * *$ & $-0.069 * * *$ \\
\hline & $(10.416)$ & $(6.031)$ & $(4.606)$ & $(4.419)$ & $(-5.589)$ & $(-6.129)$ \\
\hline & $\begin{array}{l}\text { Subjective } \\
\text { wellbeing }\end{array}$ & $\begin{array}{l}\text { Unemployment } \\
\text { insurance }\end{array}$ & Superannuation & $\begin{array}{l}\text { Industrial injury } \\
\text { insurance }\end{array}$ & $\begin{array}{l}\text { House provident } \\
\text { fund }\end{array}$ & \\
\hline \multirow[t]{2}{*}{ Nearest neighbour matching } & 0.424 & $0.180 * * *$ & $0.252 * * *$ & $0.238 * * *$ & $0.114 * * *$ & \\
\hline & $(1.617)$ & $(17.742)$ & $(12.339)$ & $(17.949)$ & $(11.900)$ & \\
\hline \multirow[t]{2}{*}{ Kernel matching } & $0.520 * * *$ & $0.189 * * *$ & $0.259 * * *$ & $0.251 * * *$ & $0.111 * * *$ & \\
\hline & $(3.056)$ & $(29.475)$ & $(21.225)$ & $(17.958)$ & $(12.936)$ & \\
\hline \multirow[t]{2}{*}{ Stratification matching } & $0.450 * *$ & $0.185^{* * *}$ & $0.255^{* * *}$ & $0.249 * * *$ & $0.109 * * *$ & \\
\hline & $(2.326)$ & $(14.498)$ & $(21.439)$ & $(23.583)$ & $(13.424)$ & \\
\hline
\end{tabular}


Table 9 Average treatment effect on the treated (ATT) of labour contract among urban workers

\begin{tabular}{|c|c|c|c|c|c|c|}
\hline & Hourly wage & Ln hourly wage & Monthly wage & $\begin{array}{l}\text { Ln monthly } \\
\text { wage }\end{array}$ & Working hours & $\begin{array}{l}\text { Ln monthly } \\
\text { working hours }\end{array}$ \\
\hline \multirow[t]{2}{*}{ Nearest neighbour matching } & $6.514 * * *$ & $0.501 * * *$ & $954.815 * * *$ & $0.454 * * *$ & -8.401 & -0.056 \\
\hline & $(9.335)$ & $(8.036)$ & $(13.207)$ & $(5.500)$ & $(-0.772)$ & $(-1.899)$ \\
\hline \multirow[t]{2}{*}{ Kernel matching } & $6.047 * * *$ & $0.525 * * *$ & $934.062 * * *$ & $0.477 * * *$ & -9.895 & -0.046 \\
\hline & $(11.431)$ & $(14.730)$ & $(11.472)$ & $(12.188)$ & $(-1.751)$ & $(-1.626)$ \\
\hline \multirow[t]{3}{*}{ Stratification matching } & $5.530 * * *$ & $0.442 * * *$ & $821.602 * * *$ & $0.410 * * *$ & -8.290 & -0.038 \\
\hline & $(5.388)$ & $(5.987)$ & $(6.203)$ & $(6.267)$ & $(-1.613)$ & $(-1.385)$ \\
\hline & $\begin{array}{l}\text { Subjective } \\
\text { wellbeing }\end{array}$ & $\begin{array}{l}\text { Unemployment } \\
\text { insurance }\end{array}$ & Superannuation & $\begin{array}{c}\text { Industrial injury } \\
\text { insurance }\end{array}$ & $\begin{array}{c}\text { House provident } \\
\text { fund }\end{array}$ & \\
\hline \multirow[t]{2}{*}{ Nearest neighbour matching } & $2.006 * * *$ & $0.419 * * *$ & $0.356 * * *$ & $0.389 * * *$ & $0.461 * * *$ & \\
\hline & $(4.327)$ & $(5.472)$ & $(5.104)$ & $(18.102)$ & $(17.869)$ & \\
\hline \multirow[t]{2}{*}{ Kernel matching } & $1.820 * * *$ & $0.458 * * *$ & $0.272 * * *$ & $0.414 * * *$ & $0.462 * * *$ & \\
\hline & $(4.608)$ & (15.947) & $(9.498)$ & $(12.614)$ & $(20.601)$ & \\
\hline \multirow[t]{2}{*}{ Stratification matching } & $1.886 * * *$ & $0.447 * * *$ & $0.341 * * *$ & $0.393 * * *$ & $0.439 * * *$ & \\
\hline & $(3.505)$ & $(10.029)$ & $(6.162)$ & $(10.496)$ & $(18.650)$ & \\
\hline
\end{tabular}


Table 10 Heterogeneous treatment effect (HTE) of labour contract among migrant workers

\begin{tabular}{|c|c|c|c|c|c|c|c|c|}
\hline \multirow{2}{*}{$\begin{array}{l}\text { Treatment effect by strata } \\
1\end{array}$} & \multicolumn{2}{|c|}{ Ln hourly wage } & \multicolumn{2}{|c|}{ Ln monthly wage } & \multicolumn{2}{|c|}{ Ln monthly working hours } & \multicolumn{2}{|c|}{ Subjective wellbeing } \\
\hline & 0.0696 & $(1.42)$ & 0.0363 & $(0.83)$ & $-0.0388 *$ & $(-1.76)$ & $1.291 * * *$ & $(2.83)$ \\
\hline 2 & $0.136 * * *$ & $(3.16)$ & 0.0592 & $(1.57)$ & $-0.0778 * * *$ & $(-4.39)$ & 0.456 & $(1.12)$ \\
\hline 3 & 0.0456 & $(0.86)$ & 0.0352 & $(0.73)$ & $-0.0583 * *$ & $(-3.22)$ & 0.572 & $(1.53)$ \\
\hline 4 & 0.0422 & $(0.82)$ & -0.0635 & $(-1.38)$ & $-0.586 * * *$ & $(-3.61)$ & 0.342 & $(1.04)$ \\
\hline 5 & $0.129 * * *$ & $(3.80)$ & $0.0748 * * *$ & $(2.58)$ & -0.0156 & $(-0.67)$ & -0.0739 & $(-0.15)$ \\
\hline 6 & $0.144 * * *$ & $(4.22)$ & $0.0993 * * *$ & $(3.37)$ & $-0.0546 * *$ & $(-2.31)$ & 0.170 & $(0.34)$ \\
\hline 7 & $0.128 * *$ & $(2.41)$ & 0.0593 & $(1.48)$ & $-0.0848 * *$ & $(-3.24)$ & 0.643 & $(1.27)$ \\
\hline 8 & $0.291 * * *$ & $(4.25)$ & $0.110 * *$ & $(2.05)$ & $-0.145^{* * *}$ & $(-3.63)$ & 1.159 & $(1.43)$ \\
\hline 9 & $0.450 * * *$ & $(3.26)$ & $0.292 * * *$ & $(2.78)$ & -0.0414 & $(-0.60)$ & 1.180 & $(1.01)$ \\
\hline \multicolumn{9}{|l|}{ Linear trend } \\
\hline Slope & $0.0202 * * *$ & $(2.67)$ & $0.0130 * *$ & $(2.03)$ & -0.00311 & $(-0.83)$ & -0.0479 & $(-0.63)$ \\
\hline Constant & 0.0328 & $(0.87)$ & 0.00277 & $(0.08)$ & $-0.0477 * *$ & $(-2.93)$ & $0.714 * *$ & $(2.09)$ \\
\hline Treatment effect by strata & \multicolumn{2}{|c|}{ Unemployment insurance } & \multicolumn{2}{|c|}{ Superannuation } & \multicolumn{2}{|c|}{ Industrial injury insurance } & \multicolumn{2}{|c|}{ House provident fund } \\
\hline 1 & $0.0323 * * *$ & $(2.65)$ & $0.0632 * * *$ & $(3.38)$ & $0.0609 * * *$ & $(3.46)$ & 0.00599 & $(1.28)$ \\
\hline 2 & 0.0186 & $(1.46)$ & $0.0551 * * *$ & $(3.31)$ & $0.0622 * * *$ & $(3.06)$ & -0.00221 & $(-0.27)$ \\
\hline 3 & 0.00791 & $(0.41)$ & 0.0274 & $(1.06)$ & 0.0100 & $(0.36)$ & 0.00684 & $(0.52)$ \\
\hline 4 & $0.0672 * * *$ & $(2.69)$ & $0.116 * * *$ & (3.77) & $0.107 * * *$ & $(3.35)$ & 0.0188 & (1.14) \\
\hline 5 & $0.106 * * *$ & (5.72) & $0.140 * * *$ & $(5.95)$ & $0.139 * * *$ & $(5.83)$ & $0.0430 * * *$ & (3.17) \\
\hline 6 & $0.138 * * *$ & $(5.56)$ & $0.224 * * *$ & $(7.25)$ & $0.217 * * *$ & (7.15) & $0.0919 * * *$ & $(4.65)$ \\
\hline 7 & $0.294 * * *$ & $(5.58)$ & $0.387 * * *$ & $(6.88)$ & $0.338 * * *$ & $(5.98)$ & $0.162 * * *$ & $(3.76)$ \\
\hline 8 & $0.398 * * *$ & (5.39) & $0.431 * * *$ & (5.84) & $0.493 * * *$ & (6.74) & $0.172 * * *$ & $(2.63)$ \\
\hline 9 & $0.404 * * *$ & $(2.76)$ & $0.654 * * *$ & $(5.07)$ & $0.588 * * *$ & $(4.28)$ & $0.439 * * *$ & $(3.05)$ \\
\hline \multicolumn{9}{|l|}{ Linear trend } \\
\hline Slope & $0.0278 * * *$ & $(7.45)$ & $0.0401 * * *$ & $(8.47)$ & $0.0379 * * *$ & (7.98) & $0.0133 * * *$ & $(5.64)$ \\
\hline Constant & $-0.0239 *$ & $(-1.93)$ & -0.0216 & $(-1.26)$ & -0.0145 & $(-0.83)$ & $-0.0139 * *$ & $(-2.37)$ \\
\hline
\end{tabular}

$\mathrm{N}=4756$

$z$ statistics in parentheses

* $p<0.10,{ }^{* *} p<0.05,{ }^{* * *} p<0.01$ 
Table 11 Heterogeneous treatment effect (HTE) of labour contract among urban workers

\begin{tabular}{|c|c|c|c|c|c|c|c|c|}
\hline \multirow{2}{*}{$\begin{array}{l}\text { Treatment effect by strata } \\
1\end{array}$} & \multicolumn{2}{|c|}{ Ln hourly wage } & \multicolumn{2}{|c|}{ Ln monthly wage } & \multicolumn{2}{|c|}{ Ln monthly working hours } & \multicolumn{2}{|c|}{ Subjective wellbeing } \\
\hline & $0.485^{* *}$ & $(2.55)$ & $0.585^{* * *}$ & $(4.12)$ & 0.0999 & $(0.71)$ & 0.210 & $(0.14)$ \\
\hline 2 & $0.140 *$ & $(1.70)$ & $0.166^{* *}$ & $(2.30)$ & 0.0252 & $(0.46)$ & 0.940 & $(0.72)$ \\
\hline 3 & 0.130 & $(1.55)$ & $0.173 * *$ & $(2.39)$ & 0.0393 & $(0.82)$ & 0.804 & $(0.78)$ \\
\hline 4 & $0.204 *$ & $(1.73)$ & $0.212 * *$ & $(2.00)$ & 0.0125 & $(0.19)$ & 0.869 & $(0.88)$ \\
\hline 5 & 0.0641 & $(0.55)$ & 0.0528 & $(0.47)$ & 0.00875 & $(0.15)$ & -0.104 & $(-0.15)$ \\
\hline 6 & -0.0863 & $(-0.51)$ & -0.0600 & $(-0.40)$ & 0.0263 & $(0.32)$ & 0.988 & $(1.37)$ \\
\hline 7 & $0.263 * * *$ & $(2.83)$ & $0.225^{* * *}$ & $(2.74)$ & -0.0432 & $(-0.95)$ & 0.489 & $(0.66)$ \\
\hline 8 & $0.236 * * *$ & $(2.87)$ & $0.208 * * *$ & $(2.90)$ & -0.0271 & $(-0.88)$ & 1.140 & $(1.50)$ \\
\hline 9 & $0.475 * * *$ & $(5.28)$ & $0.395 * * *$ & $(4.93)$ & $-0.0917 * *$ & $(-2.25)$ & $2.537 * *$ & $(1.96)$ \\
\hline 10 & $0.620 * * *$ & (4.39) & $0.537 * * *$ & (3.98) & -0.0747 & $(-1.51)$ & $4.262 * *$ & $(2.40)$ \\
\hline 11 & $0.533 * * *$ & $(3.32)$ & $0.537 * * *$ & $(3.58)$ & 0.00711 & $(0.15)$ & $3.447 * *$ & $(2.17)$ \\
\hline 12 & $0.404 * *$ & $(2.01)$ & $0.377 * *$ & (1.98) & -0.0266 & $(-0.41)$ & -- & -- \\
\hline \multicolumn{9}{|l|}{ Linear trend } \\
\hline Slope & $0.0367 * * *$ & $(3.51)$ & $0.0207 * *$ & $(2.24)$ & $-0.00955^{*}$ & $(-1.91)$ & $0.255^{*} *$ & $(2.03)$ \\
\hline Constant & 0.0368 & $(0.53)$ & $0.126 * *$ & $(2.08)$ & 0.0484 & $(1.24)$ & -0.570 & $(-0.72)$ \\
\hline Treatment effect by strata & \multicolumn{2}{|c|}{ Unemployment insurance } & \multicolumn{2}{|c|}{ Superannuation } & \multicolumn{2}{|c|}{ Industrial injury insurance } & \multicolumn{2}{|c|}{ House provident fund } \\
\hline 1 & 0.0974 & $(1.03)$ & $0.242 *$ & $(1.83)$ & $0.149 *$ & $(1.81)$ & 0.0744 & $(1.23)$ \\
\hline 2 & $0.186^{* * *}$ & $(3.22)$ & $0.120 *$ & (1.88) & $0.179 * * *$ & $(3.43)$ & -0.0153 & $(-0.49)$ \\
\hline 3 & $0.280 * * *$ & (4.47) & $0.241 * * *$ & (3.67) & $0.295 * * *$ & $(5.32)$ & $0.0926 * *$ & $(2.33)$ \\
\hline 4 & $0.206^{* * *}$ & (2.58) & $0.223 * * *$ & $(2.83)$ & $0.191 * * *$ & $(2.58)$ & $0.138 * *$ & $(2.35)$ \\
\hline 5 & 0.156 & (1.61) & $0.203 * *$ & $(2.25)$ & $0.219 * *$ & (2.39) & 0.0974 & $(1.36)$ \\
\hline 6 & $0.235^{*}$ & (1.93) & 0.146 & (1.23) & $0.275^{* *}$ & $(2.48)$ & $0.200 * *$ & $(2.16)$ \\
\hline 7 & $0.375 * * *$ & (5.83) & $0.188 * * *$ & (3.12) & $0.321 * * *$ & (5.04) & $0.195 * * *$ & $(3.55)$ \\
\hline 8 & $0.390 * * *$ & (6.55) & $0.201 * * *$ & $(3.83)$ & $0.380 * * *$ & $(6.47)$ & $0.245^{* * *}$ & $(4.40)$ \\
\hline 9 & $0.477 * * *$ & (7.49) & $0.278 * * *$ & (5.50) & $0.429 * * *$ & (6.63) & $0.372 * * *$ & $(5.77)$ \\
\hline 10 & $0.395 * * *$ & (4.53) & $0.264 * * *$ & (4.30) & $0.370 * * *$ & (3.93) & $0.524 * * *$ & $(5.62)$ \\
\hline 11 & $0.380 * * *$ & (3.77) & $0.288 * * *$ & $(3.95)$ & $0.395 * * *$ & (3.54) & $0.356^{* * *}$ & $(3.42)$ \\
\hline 12 & $0.505 * * *$ & (4.01) & $0.350 * * *$ & $(3.77)$ & $0.315 * *$ & $(2.23)$ & $0.583 * * *$ & $(5.48)$ \\
\hline \multicolumn{9}{|l|}{ Linear trend } \\
\hline Slope & $0.0321 * * *$ & (4.66) & $0.0126^{*}$ & $(1.95)$ & $0.0249 * * *$ & $(3.71)$ & $0.0460 * * *$ & $(8.57)$ \\
\hline Constant & $0.119 * *$ & $(2.53)$ & $0.141 * * *$ & $(2.86)$ & $0.150 * * *$ & $(3.49)$ & $-0.0737 * *$ & $(-2.47)$ \\
\hline
\end{tabular}

$z$ statistics in parentheses

$p<0.10,{ }^{* *} p<0.05,{ }^{* * *} p<0.01$ 
Appendix 1: Wage of migrant and urban workers (OLS regression with propensity score as a proxy of ability)

\begin{tabular}{|c|c|c|c|c|c|c|c|c|}
\hline \multirow[b]{3}{*}{ Male } & \multicolumn{4}{|c|}{ Migrant workers } & \multicolumn{4}{|c|}{ Urban workers } \\
\hline & \multicolumn{2}{|c|}{ Ln hourly wage } & \multicolumn{2}{|c|}{ Ln monthly wage } & \multicolumn{2}{|c|}{ Ln hourly wage } & \multicolumn{2}{|c|}{ Ln monthly wage } \\
\hline & $0.104 * * *$ & $(6.37)$ & $0.127 * * *$ & $(9.28)$ & $0.181 * * *$ & $(11.38)$ & $0.219 * * *$ & $(15.30)$ \\
\hline Married & 0.0196 & $(0.98)$ & 0.0119 & $(0.71)$ & $0.0740 * * *$ & $(3.14)$ & $0.0741 * * *$ & $(3.48)$ \\
\hline Poor health & $-0.292 * * *$ & $(-3.33)$ & $-0.145^{* *}$ & $(-1.98)$ & $-0.257 * * *$ & $(-4.34)$ & $-0.249 * * *$ & $(-4.72)$ \\
\hline Schooling & $0.0634 * * *$ & $(10.05)$ & $0.0372 * * *$ & $(7.08)$ & $0.0583 * * *$ & $(19.76)$ & $0.0563 * * *$ & $(21.15)$ \\
\hline Work experience & $0.0564 * * *$ & $(12.38)$ & $0.0420 * * *$ & $(11.06)$ & $0.0257 * * *$ & $(8.70)$ & $0.0294 * * *$ & (11.02) \\
\hline Work experience ${ }^{2}$ & $-0.00201 * * *$ & $(-8.31)$ & $-0.00135 * * *$ & $(-6.71)$ & $-0.000413^{* * *}$ & $(-5.78)$ & $-0.000557 * * *$ & $(-8.67)$ \\
\hline Has labour contract & $0.120 * * *$ & $(8.52)$ & $0.0590 * * *$ & $(5.03)$ & $0.259 * * *$ & $(8.80)$ & $0.248 * * *$ & $(9.34)$ \\
\hline Received occupational training & $0.107 * * *$ & $(4.42)$ & $0.0760 * * *$ & $(3.78)$ & $0.0953 * * *$ & $(5.60)$ & $0.0989 * * *$ & $(6.45)$ \\
\hline Employer has more than 50 employees & $0.154 * * *$ & $(3.88)$ & 0.0195 & $(0.59)$ & $0.178 * * *$ & $(8.44)$ & $0.209 * * *$ & $(10.99)$ \\
\hline \multicolumn{9}{|c|}{ Employer ownership (ref: micro-entrepreneur and others) } \\
\hline SOE/COE/government agency and affiliate & $0.245 * * *$ & $(3.53)$ & 0.0330 & $(0.57)$ & $0.168 * * *$ & $(3.98)$ & $0.132 * * *$ & $(3.46)$ \\
\hline Private-owned, foreign-owned and joint-venture & $0.172 * * *$ & $(3.35)$ & 0.0260 & $(0.61)$ & $0.195 * * *$ & $(4.90)$ & $0.190 * * *$ & $(5.29)$ \\
\hline \multicolumn{9}{|l|}{ Employment sector (ref: others) } \\
\hline Manufacturing & $0.0670 * * *$ & $(3.15)$ & $0.0336 *$ & $(1.90)$ & $-0.180 * * *$ & $(-8.61)$ & $-0.161 * * *$ & $(-8.55)$ \\
\hline Construction & 0.0107 & $(0.18)$ & $0.171 * * *$ & $(3.42)$ & $-0.0761 *$ & $(-1.74)$ & -0.0382 & $(-0.97)$ \\
\hline Wholesale and retail services & -0.00463 & $(-0.22)$ & 0.0147 & $(0.85)$ & $-0.114 * * *$ & $(-4.10)$ & $-0.105 * * *$ & $(-4.19)$ \\
\hline Hotel and catering services & $-0.125 * * *$ & $(-4.50)$ & $-0.0602 * * *$ & $(-2.59)$ & $-0.190 * * *$ & $(-3.96)$ & $-0.166 * * *$ & $(-3.83)$ \\
\hline Meals & 0.0388 & $(1.42)$ & -0.00290 & $(-0.13)$ & $0.179 * * *$ & $(9.98)$ & $0.202 * * *$ & $(12.45)$ \\
\hline Housing & $-0.0687 * * *$ & $(-4.60)$ & $-0.0336 * * *$ & $(-2.70)$ & 0.0420 & $(0.93)$ & 0.0385 & $(0.94)$ \\
\hline \multicolumn{9}{|l|}{ Region (ref: south) } \\
\hline East & $0.0758 * * *$ & $(2.72)$ & 0.0341 & $(1.47)$ & $-0.307 * * *$ & $(-12.53)$ & $-0.303 * * *$ & $(-13.67)$ \\
\hline Central and west & $-0.390 * * *$ & $(-13.03)$ & $-0.276 * * *$ & $(-11.07)$ & $-0.648 * * *$ & $(-28.70)$ & $-0.613 * * *$ & $(-30.04)$ \\
\hline Propensity score & $0.768 * *$ & $(2.43)$ & 0.0936 & $(0.36)$ & 0.185 & $(1.20)$ & $0.399 * * *$ & $(2.87)$ \\
\hline Constant & $0.489 *$ & $(1.95)$ & $6.597 * * *$ & $(31.46)$ & $1.128 * * *$ & $(11.61)$ & $6.200 * * *$ & $(70.68)$ \\
\hline $\mathrm{N}$ & 4733 & & 4754 & & 6201 & & 6230 & \\
\hline Adjusted $\mathrm{R}^{2}$ & 0.318 & & 0.298 & & 0.334 & & 0.360 & \\
\hline
\end{tabular}

$t$ statistics in parentheses

${ }^{*} p<0.10,{ }^{* *} p<0.05,{ }^{* * *} p<0.01$ 
Appendix 2: Monthly working hours of migrant and urban workers (IV regression)

\begin{tabular}{|c|c|c|c|c|}
\hline & \multicolumn{2}{|c|}{ Migrant workers } & \multicolumn{2}{|c|}{ Urban workers } \\
\hline Ln monthly wage & $0.0328 * *$ & $(2.36)$ & -0.0503 & $(-0.67)$ \\
\hline Schooling & $-0.0153 * * *$ & $(-4.31)$ & -0.00157 & $(-0.39)$ \\
\hline Work experience & $-0.00967 * *$ & $(-2.31)$ & 0.00271 & $(1.25)$ \\
\hline Work experience ${ }^{2}$ & $0.000363 * *$ & $(2.39)$ & $-0.000122 * * *$ & $(-2.67)$ \\
\hline Male & $0.0390 * * *$ & $(2.93)$ & $0.0478 * * *$ & $(2.69)$ \\
\hline Married & $0.0219 * * *$ & $(2.97)$ & 0.0117 & $(0.96)$ \\
\hline Poor health & 0.0113 & $(0.35)$ & 0.0182 & $(0.59)$ \\
\hline Has labour contract & $-0.0630 * * *$ & $(-6.91)$ & -0.00676 & $(-0.31)$ \\
\hline Received occupational training & 0.00721 & $(0.73)$ & -0.00211 & $(-0.22)$ \\
\hline Employer has more than 50 employees & $-0.0562 * * *$ & $(-7.28)$ & 0.0217 & $(1.40)$ \\
\hline \multicolumn{5}{|l|}{ Employer ownership (ref: micro-entrepreneur and others) } \\
\hline SOE/COE/government agency and affiliate & $-0.0723 * * *$ & $(-6.21)$ & $-0.0726 * * *$ & $(-5.16)$ \\
\hline Private-owned, foreign-owned and joint-venture & $-0.0422 * * *$ & $(-4.84)$ & $-0.0302 *$ & $(-1.78)$ \\
\hline \multicolumn{5}{|l|}{ Employment sector (ref: others) } \\
\hline Manufacturing & -0.0142 & $(-1.37)$ & 0.0132 & $(0.87)$ \\
\hline Construction & $0.0375^{*}$ & $(1.78)$ & $0.0458 * *$ & $(2.38)$ \\
\hline Wholesale and retail services & 0.00954 & $(0.89)$ & 0.0128 & $(0.91)$ \\
\hline Hotel and catering services & $0.0246 * *$ & $(2.19)$ & 0.0226 & $(0.94)$ \\
\hline Meals & 0.00618 & $(0.76)$ & $0.0281 *$ & $(1.70)$ \\
\hline Housing & $0.0415 * * *$ & $(5.01)$ & -0.00528 & $(-0.26)$ \\
\hline \multicolumn{5}{|l|}{ Region (ref: south) } \\
\hline East & 0.00449 & $(0.48)$ & -0.0139 & $(-0.54)$ \\
\hline Central and west & $0.0701 * * *$ & $(2.70)$ & 0.00606 & $(0.13)$ \\
\hline Constant & $5.358 * * *$ & $(8.82)$ & $5.510 * * *$ & $(11.43)$ \\
\hline $\mathrm{N}$ & 4733 & & 6201 & \\
\hline Adjusted $\mathrm{R}^{2}$ & 0.140 & & 0.018 & \\
\hline \multicolumn{5}{|l|}{ Regression diagnostics } \\
\hline \multicolumn{5}{|l|}{ First-stage regression summary statistics } \\
\hline F test & $13.29 * * *$ & & $21.72 * * *$ & \\
\hline $\mathrm{R}^{2}$ & 0.3077 & & 0.3633 & \\
\hline Adjusted $\mathrm{R}^{2}$ & 0.3046 & & 0.3641 & \\
\hline Minimum eigenvalue statistic ( $5 \%$ critical value) & $23.7391(19.93)$ & & $21.7205(19.93)$ & ‘ \\
\hline Test of overidentifying restrictions: $p$ value & 0.8946 & & 0.4113 & \\
\hline
\end{tabular}

$t$ statistics in parentheses unless specified

${ }^{*} p<0.10,{ }^{* *} p<0.05,{ }^{* * *} p<0.01$ 